\title{
Acute toxicity, accumulation and tissue distribution of copper in the blue crab Callinectes sapidus acclimated to different salinities: In vivo and in vitro studies
}

\author{
Camila De Martinez Gaspar Martins ${ }^{a}$, Indianara Fernanda Barcarolli ${ }^{b}$, Eliana Jaime de Menezes ${ }^{\text {b }}$, \\ Marina Mussoi Giacomin ${ }^{\mathrm{b}}$, Chris M. Wood ${ }^{\mathrm{c}}$, Adalto Bianchini ${ }^{\mathrm{a}, \mathrm{b}, *}$ \\ a Programa de Pós-Graduação em Ciências Fisiológicas - Fisiologia Animal Comparada, Instituto de Ciências Biológicas, Universidade Federal do Rio Grande (FURG), \\ Campus Carreiros, Av. Itália km 8, 96201-900, Rio Grande, RS, Brazil \\ b Instituto de Ciências Biológicas, Universidade Federal do Rio Grande (FURG), Campus Carreiros, Av. Itália km 8, 96201-900, Rio Grande, RS, Brazil \\ ${ }^{\mathrm{c}}$ McMaster University, Department of Biology, 1280 Main Street West, Hamilton, ON, Canada L8S 4K1
}

\section{A R T I C L E I N F O}

\section{Article history:}

Received 14 April 2010

Received in revised form 7 September 2010

Accepted 10 September 2010

\section{Keywords:}

Accumulation

Acute toxicity

Blue crab

Copper

Gills

Organ-specific distribution

Salinity

\begin{abstract}
A B S T R A C T
In vivo and in vitro studies were performed to evaluate acute toxicity, organ-specific distribution, and tissue accumulation of copper in Callinectes sapidus acclimated to two different experimental salinities ( 2 and $30 \mathrm{ppt}$ ). Blue crabs were quite tolerant to copper. Acute dissolved copper toxicity (96-h $\mathrm{LC}_{50}$ and its corresponding $95 \%$ confident interval) was higher at salinity 2 ppt $(5.3(3.50-8.05) \mu \mathrm{M} \mathrm{Cu})$ than at $30 \mathrm{ppt}(53.0(27.39-102.52) \mu \mathrm{M} \mathrm{Cu})$. The difference between salinities can be completely explained based on the water chemistry because it disappeared when 96-h $\mathrm{LC}_{50}$ values were expressed as the free $\mathrm{Cu}^{2+}$ ion $(3.1(1.93-4.95) \mu \mathrm{M}$ free $\mathrm{Cu}$ at $2 \mathrm{ppt}$ versus $5.6(2.33-13.37) \mu \mathrm{M}$ free $\mathrm{Cu}$ at $30 \mathrm{ppt})$ or the $\mathrm{Cu}^{2+}$ activity $(1.4(0.88-2.26) \mu \mathrm{M}$ Cu activity at $2 \mathrm{ppt}$ versus $1.7(0.71-4.07) \mu \mathrm{M}$ Cu activity at $30 \mathrm{ppt})$. The relationships between gill Cu burden and \% mortality were very similar at 2 and $30 \mathrm{ppt}$, in accord with the Biotic Ligand Model. In vivo experiments showed that copper concentration in the hemolymph is not dependent on metal concentration in the surrounding medium at either experimental salinity. They also showed that copper flux into the gills is higher than into other tissues analyzed, and that anterior and posterior gills are similarly important sites of copper accumulation at both experimental salinities. In vitro experiments with isolated-perfused gills showed that there is a positive relationship between copper accumulation in this tissue and the metal concentration in the incubation media for both anterior and posterior gills. A similar result was observed at both low and high salinities. Furthermore, in vitro experiments showed that copper accumulation in posterior gills is also positively and strongly dependent on the incubation time with copper. Gill copper accumulation occurred at a lower rate in the first $2 \mathrm{~h}$ of metal exposure, increasing markedly after this "steady-state" period. This finding was corroborated by a significant increase in copper influx to the gill perfusate (corresponding to crab hemolymph) after this time, measured using ${ }^{64} \mathrm{Cu}$. In vivo, after uptake from solution, ${ }^{64} \mathrm{Cu}$ was primarily accumulated in the gills and the rest of the body rather than in the hemolymph, hepatopancreas, or other internal tissues. Overall, the present findings indicate that gills are a key target organ for copper accumulation, as well as an important biological barrier against the excessive uptake of copper into the hemolymph and the subsequent distribution of this metal to internal organs of the blue crab.
\end{abstract}

(C) 2010 Elsevier B.V. All rights reserved.

\section{Introduction}

Copper is an essential micronutrient required by all living organisms for a variety of physiological and biochemical processes. In crustaceans, copper is also a component of the respiratory pigment

\footnotetext{
* Corresponding author at: Universidade Federal do Rio Grande (FURG), Instituto de Ciências Biológicas, Av. Itália km 8, Campus Carreiros, 96201-900, Rio Grande, RS, Brazil, Tel.: +55 533233 6853; fax: +55 5332336848 .

E-mail addresses: adaltobianchini@furg.br, adalto@octopus.furg.br (A. Bianchini)
}

hemocyanin, participating in oxygen transport (Engel and Brouwer, 1987; Rainer and Brouwer, 1993). Although copper is an essential element, it can be potentially toxic to aquatic organisms when available in excess in the water.

While there are important natural sources of copper, multiple human activities (industries, agriculture, harbors) have considerably increased the input of this metal in estuarine and marine environments around the world (Flegal and Sanudo-Wilhelmy, 1993; van Geen and Luoma, 1999; Niencheski and Baumgarten, 2000; Morillo et al., 2005; Niencheski et al., 2006; D'Adamo et al., 2008). For example, in Patos Lagoon estuary (Southern Brazil), the largest coastal water body in South America, an increase 
of approximately 15-fold in copper concentration in water has been documented in the last 20 years (Seeliger and Knak, 1982; Baumgarten and Niencheski, 1998).

Aquatic organisms take up copper in proportion to the dissolved concentration of the metal in water (Rainbow, 1995). Generally, uptake occurs throughout epithelial surfaces related to absorption and excretion of ions such as the gill membranes of fish and crustaceans (MacRae et al., 1999; Santore et al., 2001; Paquin et al., 2002; Grosell et al., 2007). Copper can compete with other cations for binding and active uptake sites at the gills (MacRae et al., 1999; Santore et al., 2001; Paquin et al., 2002; Grosell et al., 2007). Once absorbed, copper may accumulate in various tissues, especially gills, and exert diverse toxic effects (MacRae et al., 1999; Arnold et al., 2005; Grosell et al., 2007). In freshwater organisms, it is well known that copper interferes with $\mathrm{Na}^{+}$uptake pathways in gills. The resulting impairment in the $\mathrm{Na}^{+}$gradient, in addition to the inhibitory effects of copper on enzymes related to osmoregulation, i.e. $\mathrm{Na}^{+} / \mathrm{K}^{+}$-ATPase and carbonic anhydrase, may be the mechanisms for acute toxicity (Vitale et al., 1999; Grosell and Wood, 2002; Bianchini et al., 2004). On the other hand, high copper concentrations can also cause mortality through respiratory disruption (Grosell et al., 2002).

Water chemistry greatly influences copper bioavailability and its consequent toxicity (MacRae et al., 1999; Di Toro et al., 2001; Grosell et al., 2002). Increases in salinity can result in lower free metal ion levels, which are a consequence of a increased metal complexation by chlorides in higher salinities, and increased competition by cations such as $\mathrm{Na}^{+}, \mathrm{Mg}^{2+}$, and $\mathrm{Ca}^{2+}$ (Bianchini and Gilles, 2000; Paquin et al., 2000; Bianchini et al., 2002; Gensemer et al., 2002; Janssen et al., 2003). For that reason, increases in salinity are generally associated with decreased uptake rates of many trace metals by marine invertebrates and fish (Jones, 1975; Reardon and Harrell, 1990; Bambang et al., 1995; Verslycke et al., 2003; Pinho et al., 2007), suggesting that high salinity can act as a protective factor against copper toxicity.

Changes in water salinity influence not only metal bioavailability but also cause physiological alterations in aquatic organisms in order to maintain ionic and osmotic balance. Copper toxicity can vary depending on osmoregulatory strategies adopted by the organisms. For example, the killifish Fundulus heteroclitus is more sensitive to copper in freshwater when it is hyperosmoregulating than at a salinity of $10 \mathrm{ppt}$ that is close to its isosmotic point (12 ppt) (Grosell et al., 2007). The blue crab Callinectes sapidus is a very widespread euryhaline species inhabiting estuaries and coastal areas (Rathbun, 1930). These crabs show different osmoregulatory strategies according to the salinity of the surrounding medium. At high salinity (>20 ppt), they osmoconform, while at lower salinity (<15 ppt) they hyperosmoregulate (Leffler, 1975). All these characteristics make the blue crab a good model to investigate mechanisms involved in copper toxicity among different salinities.

The Biotic Ligand Model (BLM) is a computational tool currently employed to define water quality criteria for copper in fresh waters (WQC) (US-EPA 2003). The BLM framework is based on both organism physiology and water chemistry (MacRae et al., 1999; Santore et al., 2001; Paquin et al., 2002). This model is based on the premise that there is a strong correlation between metal bioavailability in water, metal concentration on or into the biotic ligand (generally the gill), and its subsequent acute toxicity (Di Toro et al., 2001; De Schamphelaere et al., 2002; Grosell et al., 2007). At present, many efforts are being made to extend the BLM from freshwater to saltwater conditions (Bianchini et al., 2003; Bianchini et al., 2004; Grosell et al., 2007). For that reason, studies concerning marine and estuarine organisms are critical for the improvement of the BLM.

The aim of the present study was to clarify mechanisms of copper toxicity in a crustacean that can live across a wide range of salinities, with the goal of ultimately developing a BLM approach for saltwater and estuarine organisms at different salinities. For that, we analyzed copper accumulation and toxicity in the blue crab C. sapidus acclimated to low (2 ppt) and high (30 ppt) salinities by using both whole animal and isolated-perfused gill approaches Pequeux and Gilles (1978). We investigated copper uptake at low salinity (2 ppt) in detail, using both "cold" and radioactive $\left({ }^{64} \mathrm{Cu}\right)$ techniques.

\section{Material and methods}

Firstly, copper toxicity and tissue distribution and accumulation were evaluated in blue crabs $C$. sapidus acclimated to 2 and 30 ppt. Secondly, copper uptake and tissue distribution and accumulation were analyzed in greater detail in crabs acclimated to $2 \mathrm{ppt}$, a situation in which they must hyperosmoregulate by active ion uptake from the water. Both in vivo and in vitro experiments were performed in the first and second groups of experiments. The first group of experiments was performed in Brazil (Universidade Federal do Rio Grande, Rio Grande, RS). The second group of experiments was performed in Canada (McMaster University, Hamilton, $\mathrm{ON})$.

\subsection{Animal collection and acclimation}

Male blue crabs $C$. sapidus in stage C or early D of the intermoult cycle (Drach and Tchernigovtzeff, 1967) were used to perform experiments in the present study. For tests performed in Brazil, crabs were collected at Marinheiros Island, a non coppercontaminated site at the Patos Lagoon estuary (Rio Grande, RS, Southern Brazil) (Baumgarten and Niencheski, 1998). Blue crabs used in Canada were purchased from Gulf Marine Specimens Laboratories (Panacea, FL, USA).

Juvenile crabs (carapace length $=8.3 \pm 0.2 \mathrm{~cm}$; body mass $=43.4 \pm 2.5 \mathrm{~g}$ ) were used for acute toxicity and in vivo accumulation tests with copper. Adult crabs (carapace length $=12.3 \pm 0.2 \mathrm{~cm}$; body mass $=137.1 \pm 16.7 \mathrm{~g}$ ) were used for in vitro copper accumulation and uptake tests.

In the laboratory, crabs were kept for at least 1 week at either 2 or 30 ppt salinity. In both cases, acclimation media were continuously filtered (chemical and biological filters) and aerated. Temperature and photoperiod were fixed at $20^{\circ} \mathrm{C}$ and $12 \mathrm{~L}: 12 \mathrm{D}$, respectively. Crabs were fed to satiation with chopped fish three times a week.

\subsection{Acute toxicity and in vivo accumulation tests}

Acclimated juvenile crabs were kept under control conditions (without copper addition to the water) or exposed for $96 \mathrm{~h}$ to waterborne copper. Experimental media were prepared using filtered (5- $\mu \mathrm{m}$ mesh filter) saltwater at 2 and $30 \mathrm{ppt}$ collected at Cassino Beach (Rio Grande, RS, Southern Brazil. Different copper concentrations were tested at the two salinities (at $2 \mathrm{ppt}$ : 0.5, 1, 4, 7, 10, and $20 \mu \mathrm{M}$ nominal copper; at 30 ppt: 1, 10, 50,100, and $200 \mu \mathrm{M}$ nominal copper). Copper $\left(\mathrm{CuCl}_{2}\right.$; Vetec, Rio de Janeiro, RJ, Brazil) was added to the saltwater from a stock solution $(50 \mathrm{mM})$ prepared in acidified Milli- $\mathrm{Q}^{\circledR}$ water. The experimental media were allowed to pre-equilibrate for $3 \mathrm{~h}$ prior to introduction of the crabs into the test media. Crabs $(N=7)$ were exposed to copper in a precleaned $\left(1 \% \mathrm{HNO}_{3}\right)$ glass aquarium containing $5 \mathrm{~L}$ of experimental media. Temperature $\left(20^{\circ} \mathrm{C}\right)$ and photoperiod (12L:12D) were fixed. Experimental media were continuously aerated. Every $24 \mathrm{~h}$, living crabs were counted, dead crabs were removed, and test media were completely renewed. No food was provided during the test.

Non-filtered and filtered $(0.45-\mu \mathrm{m}$ mesh filter, Durapore PVDF Membrane, Millipore, São Paulo, SP, Brazil) water samples ( $10 \mathrm{ml})$ were collected from both control and copper-contaminated media prior to introduction of the crabs into the experimental media, 
and after $24 \mathrm{~h}$ of test. Water samples were placed in clean plastic Falcon ${ }^{\circledR}$ tubes and acidified $\left(0.5 \% \mathrm{HNO}_{3}\right)$ for later determination of total (non-filtered samples) and dissolved (filtered samples) copper concentrations, as described below (Section 2.6). Physicochemical characterization of the experimental media (saltwater at salinity 2 and $30 \mathrm{ppt}$ ) was performed as previously described (Pinho et al., 2007; Pinho and Bianchini, 2010). The following parameters were measured: temperature, dissolved oxygen, $\mathrm{pH}$, alkalinity, and ion $\left(\mathrm{Na}^{+}, \mathrm{K}^{+}, \mathrm{Ca}^{2+} \mathrm{Mg}^{2+}, \mathrm{Cl}^{-}\right.$and $\left.\mathrm{SO}_{4}^{-}\right)$and DOC concentration.

Following copper exposure, crabs which had been exposed to copper concentrations lower than the corresponding $96-\mathrm{h} \mathrm{LC}_{50}$ at each experimental salinity were cryoanesthetized and hemolymph was collected by puncture at the bases of the 3rd or 4th pair of pereiopods. Crabs were then killed by carapace removal, and the gills (anterior and posterior) excised. Removed gills were washed superficially in fresh saltwater at 2 or $30 \mathrm{ppt}$ and internally flushed as in Section 2.3 so as to remove haemolymph. Anterior ( $1 \mathrm{st}-4$ th pairs) and posterior (5th-8th pairs) gills were collected separately because of their different physiological functions in blue crabs, as reported in other decapods. Anterior gills are associated with gas exchange while posterior gills are related to ionic and osmoregulatory processes (Piller et al., 1995).

Collected tissues were weighed, dried, and completely digested in $1 \mathrm{ml}$ of $65 \% \mathrm{HNO}_{3}$ (Suprapur ${ }^{\circledR}$, Merck, Haar, Germany) at $60{ }^{\circ} \mathrm{C}$ for 2 days. Digested samples were centrifuged $\left(10 \mathrm{~min} ; 4^{\circ} \mathrm{C}\right.$; $10,000 \times g$; Mikro22R, Hettich, Germany) and the supernatant was collected for copper measurements, as described below (Section 2.6). Results were expressed in $\mu \mathrm{M} \mathrm{Cu} / \mathrm{g}$ wet weight.

\subsection{Gill preparation for in vitro experiments}

In vitro experiments were performed on isolated and perfused gills of adult crabs acclimated to 2 or $30 \mathrm{ppt}$. Anterior (3rd and 4th pairs) and posterior (6th and 7th pairs) gills were perfused and incubated following the procedures described by Pequeux and Gilles (1978). Saline solutions used to perfuse (S2) and incubate (W2) gills from blue crabs acclimated to 2 ppt were prepared considering the hemolymph ion composition of $C$. sapidus acclimated to salinity 2 ppt and the saltwater ion composition at salinity $2 \mathrm{ppt}$, respectively. Therefore, composition and osmolality of S2 and W2 were different, since $C$. sapidus is hyper-osmoregulating at salinity 2 ppt. However, the same saline solution was used to perfuse (S30) and incubate (W30) gills from blue crabs acclimated to salinity $30 \mathrm{ppt}$, since $C$. sapidus is osmoconforming at salinity $30 \mathrm{ppt}$. The S2 saline solution had the following composition (in $\mathrm{mM}$ ): $\mathrm{NaCl}$ $335, \mathrm{KHCO}_{3} 8, \mathrm{CaCl}_{2} 15, \mathrm{MgSO}_{4} 10, \mathrm{H}_{3} \mathrm{BO}_{3}$ 5, sodium citrate 9 , and glucose 2.8. The $\mathrm{W} 2$ saline solution had the following composition (in $\mathrm{mM}$ ): $\mathrm{NaCl} 35, \mathrm{KHCO}_{3} 0.5, \mathrm{CaCl}_{2} 0.5, \mathrm{MgSO}_{4} 5, \mathrm{H}_{3} \mathrm{BO}_{3} 5$, and glucose 2.8. The $\mathrm{S} 30$ and $\mathrm{W} 30$ saline solutions had the same composition (in mM): $\mathrm{NaCl} 370, \mathrm{KHCO}_{3} 12, \mathrm{CaCl}_{2} 20, \mathrm{MgSO}_{4} 10, \mathrm{H}_{3} \mathrm{BO}_{3}$ 5 , sodium citrate 15 , and glucose 2.8 ). The $\mathrm{pH}$ of all saline solutions was adjusted to 7.6 with Tris-Base. In order to prepare the S2 saline solution, ion hemolymph composition of crabs acclimated to salinity 2 ppt was determined using the same procedures as described by Martins and Bianchini (2009). The osmolalities of all solutions (S2: $692 \pm 4, \mathrm{~S} 30: 801 \pm 4, \mathrm{~W} 2: 87 \pm 1$ and $\mathrm{W} 30: 801 \pm 4 \mathrm{mOsm} / \mathrm{kg}$ ) were checked using a semi-micro osmometer (Knauer, Germany) based on the freezing depression.

After cryoanesthesia and sacrifice of the crab, the carapace was removed and gills were cut free from their bases and carefully rinsed with S2 or S30 saline solution for crabs acclimated to 2 or 30 ppt respectively. Hemolymph remaining in the excised gills was quickly removed by gently flushing the gill with S2 or S30 saline solution using a plastic catheter (Sondaplast, P.E. 50) attached to a plastic disposable syringe $(1 \mathrm{ml})$. This catheter was inserted into the gill afferent vessel. After gill rinsing, plastic catheters (Sondaplast ${ }^{\circledR}$ ) of appropriated diameter were clipped to the afferent and efferent vessels. The preparation was then immersed in a plastic vessel containing $15 \mathrm{ml}$ of the appropriate incubation solution (W2 or W30, see below). The incubation solution was continuously aerated.

The catheter inserted into the afferent vessel was connected to a glass balloon flask containing S2 or S30 saline solution as appropriate while the catheter inserted into the efferent vessel drained into a plastic vial to collect the perfusate. The perfusion pressure corresponded to $15-20 \mathrm{~cm} \mathrm{H}_{2} \mathrm{O}$. The level of the external incubation medium was continuously monitored over the perfusion time to check for the occurrence of possible leaks. Leaky preparations were discarded. After perfusion, gills were removed from the clip, washed, dried on filter paper, and weighed for copper content analysis, as described below.

\subsection{In vitro gill copper accumulation}

Gills (anterior and posterior) were perfused with the S2 saline solution and incubated in the W2 saline solution (2 ppt acclimated crabs) or perfused with the S30 saline solution and incubated with the W30 saline solution (30 ppt acclimated crabs). Based on results from the copper toxicity tests (96-h $\mathrm{LC}_{50}$ ), external incubation media (W2 and W30 saline solutions) containing copper at two different concentrations ( 1 and $10 \mu \mathrm{M}$ nominal copper) were tested. The copper $\left(\mathrm{CuCl}_{2}\right.$; Vetec, Rio de Janeiro, RJ, Brazil) stock solution $(500 \mu \mathrm{M})$ was prepared in acidified Milli-Q water $(0.1 \%$ $\mathrm{HNO}_{3}$; Suprapur ${ }^{\circledR}$, Merck, Haar, Germany). Copper concentration in the stock solution was checked as described in Section 2.6. Gills were also incubated in W2 saline solution (2 ppt acclimated crabs) or W30 saline solution (30 ppt acclimated crabs) without copper addition, as control groups.

Anterior gills $(N=6)$ were perfused for $4 \mathrm{~h}$ while posterior gills $(N=6)$ were perfused for 1,2 , and $4 \mathrm{~h}$. Because of our study was focused on the mechanisms of gill copper uptake, copper accumulations as a function of time were only analyzed in posterior gills since they are the major responsible sites for ion uptake in hyperosmoregulating crabs (Piller et al., 1995). After perfusion, gills were washed in the appropriate incubation saline solution (W2 or W30 saline solution) without copper, blotted dried on filter paper, weighed (wet weight), dried, and digested for copper content analysis, which was performed as described below (Section 2.6). Results were expressed in $\mu \mathrm{M} \mathrm{Cu/g}$ wet weight.

At the beginning and the end of each experiment, filtered samples of the incubation media $(5 \mathrm{ml})$ were collected and acidified $\left(0.5 \% \mathrm{HNO}_{3}\right)$ for further analyses of dissolved copper concentrations, which were performed as described below.

\subsection{Copper flux assays}

Dried $\mathrm{Cu}\left(\mathrm{NO}_{3}\right)_{2}(1 \mathrm{mg})$ was irradiated in the Nuclear Research Reactor at McMaster University (Hamilton, ON, Canada) to achieve a radioactivity level of $0.6 \mathrm{mCi}\left({ }^{64} \mathrm{Cu}\right.$; half life $\left.=12.9 \mathrm{~h}\right)$. After irradiation, $\mathrm{Cu}\left(\mathrm{NO}_{3}\right)_{2}$ was resuspended in $400 \mu \mathrm{HNO}_{3}(0.1 \mathrm{mM}), 400 \mu \mathrm{l}$ $\mathrm{NaHCO}_{3}(0.01 \mathrm{mM}$ ), and $4.2 \mathrm{ml} \mathrm{W2}$ (in vitro experiments) or saltwater at 2 ppt (in vivo experiments). The resuspended ${ }^{64} \mathrm{Cu}$ was then added to the incubation media (W2) to give a final concentration of $1 \mu \mathrm{M} \mathrm{Cu}, 0.2 \mu \mathrm{Ci} / \mathrm{ml}$ ). Considering the short half-life of ${ }^{64} \mathrm{Cu}$, all experiments were performed within the next $12 \mathrm{~h}$ after irradiation.

\subsubsection{In vitro assay}

In vitro measurements of copper flux were performed in perfused posterior gills $(N=6)$ isolated from blue crabs acclimated to $2 \mathrm{ppt}$. As mentioned above, posterior gills are the major organs responsible for ion uptake from water in hyperosmoregulating blue crabs (i.e. 2 ppt acclimated crabs). These gills were perfused with S2 saline solution and incubated in W2 saline solution containing ${ }^{64} \mathrm{Cu}$ 
$(1 \mu \mathrm{M} \mathrm{Cu} ; 0.2 \mu \mathrm{Ci} / \mathrm{ml})$ for $3 \mathrm{~h}$. Perfusion time was selected based on the results from the in vitro copper accumulation study described above. The perfusate was collected every $20 \mathrm{~min}$ over the whole experimental period $(3 \mathrm{~h}$ ). Samples were collected in glass vials and immediately assayed for gamma radioactivity. After perfusion, gills incubated with ${ }^{64} \mathrm{Cu}$ were rinsed in a solution containing a high concentration of non-radioactive $\mathrm{CuSO}_{4}(200 \mu \mathrm{M} \mathrm{Cu})$. This "cold displacement" rinse was performed to remove any loosely surfacebound isotope from the gills. Then, gills were blotted dry on filter paper, weighed, and placed into glass vials for ${ }^{64} \mathrm{Cu}$ radioactivity measurements (gamma counting). Gill copper accumulation was determined by measuring the amount of ${ }^{64} \mathrm{Cu}$ in the gills at the end of the perfusion period $(3 \mathrm{~h})$. Copper uptake into the perfusate was determined cumulatively based on the amount of ${ }^{64} \mathrm{Cu}$ measured in the efferent perfusate collected throughout $3 \mathrm{~h}$ of perfusion.

Samples $(5 \mathrm{ml})$ of the incubation media were collected $10 \mathrm{~min}$ after the isotope addition (initial) and just before the end of experiment (final). The measured radioactivities and total copper concentrations in the incubation media at the start and end of the perfusion periods was used to determine the ${ }^{64} \mathrm{Cu}$ specific activity, as outlined in Section 2.6.

\subsubsection{In vivo assay}

In vivo copper uptake measurements were performed in blue crabs $(N=7)$ acclimated to 2 ppt. Crabs were immersed individually for $6 \mathrm{~h}$ in a plastic vessel containing $1 \mu \mathrm{M}{ }^{64} \mathrm{Cu}(0.2 \mu \mathrm{Ci} / \mathrm{ml})$ dissolved in $1 \mathrm{~L}$ of artificial saltwater $(2 \mathrm{ppt})$. Samples of water $(5 \mathrm{ml})$ were collected every hour. Crab hemolymph samples $(100 \mu \mathrm{l})$ were collected with minimal disturbance, by puncture at the bases of the 3rd or 4th pair of pereiopods, after 1,2,4, and $6 \mathrm{~h}$ of the beginning of the experiment. Water and hemolymph samples were placed into glass vials and immediately assayed for ${ }^{64} \mathrm{Cu}$ gamma radioactivity. Following the isotope incubation period $(6 \mathrm{~h})$, crabs were netted out of the exposure containers and rinsed ( $1 \mathrm{~min}$ ) in a solution containing a high concentration of non-radioactive $\mathrm{CuSO}_{4}(200 \mu \mathrm{M} \mathrm{Cu})$ to remove any loosely bound ${ }^{64} \mathrm{Cu}$. After rinsing, crabs were weighed, cryoanesthetized, and killed for tissue dissection (anterior gills, posterior gills, hepatopancreas, and gonads). Tissues were weighed and placed into glass vials for measurements of ${ }^{64} \mathrm{Cu}$ radioactivity. The rest of the body (essentially muscle and carapace) was homogenized using a blender, weighed, and placed in a glass vials for radioactivity measurement $\left({ }^{64} \mathrm{Cu}\right.$ gamma counting).

In vivo copper uptake could be assessed both by the disappearance of ${ }^{64} \mathrm{Cu}$ from the water, as well as its subsequent appearance in hemolymph, dissected tissues, and the rest of the body, as outlined below.

\subsection{Analytical techniques and calculations}

Copper concentrations in stock solutions, water samples (nonfiltered and filtered) from toxicity tests, samples of the incubation media, and samples of tissues from the in vitro bioaccumulation tests were analyzed by atomic absorption spectrophotometry (AAS, Avanta 932 Plus - GBC, Hampshire, IL, USA). Copper concentrations in samples of perfusate and incubation saline solutions from the in vitro tests and in samples of the incubation media from the in vivo tests with ${ }^{64} \mathrm{Cu}$ were measured by graphite furnace atomic absorption spectroscopy (GF AAS; Varian SpectrA AA-220 with a SpectrAA GTA-110, Mulgrave, Australia).

Radioactivity from ${ }^{64} \mathrm{Cu}$ in all experimental solutions (perfusate and incubation media), tissues, and rest of the body was determined using a gamma-counter (Canberra Packard Minaxi Auto gamma 5000 series gamma-counter, Meriden, CT, USA) with an on-board program for decay correction of ${ }^{64} \mathrm{Cu}$. The ${ }^{64} \mathrm{Cu}$ radioactivity was measured immediately after the experiments because of its short half-life.
Mean measured ${ }^{64} \mathrm{Cu}$ specific activities in the incubation media over the appropriate periods from in vitro and in vivo experiments were used for copper uptake rate calculations. Specific activity expresses the counts per minute (cpm) of ${ }^{64} \mathrm{Cu}$ per $\mu \mathrm{M}$ of the total copper in the incubation media, and was calculated as:

$\mathrm{SA}=0.5\left[R_{1} / \mathrm{Cu}_{1}+R_{2} / \mathrm{Cu}_{2}\right]$

where $R_{1}$ and $R_{2}$ are ${ }^{64} \mathrm{Cu}$ radioactivities $\left(\mathrm{cpm} \mathrm{ml}{ }^{-1}\right)$ and $\mathrm{Cu}_{1}$ and $\mathrm{Cu}_{2}$ are total copper concentrations $\left(\mu \mathrm{mol} / \mathrm{ml}^{-1}\right)$ at time 1 and time 2 , respectively.

In the in vitro experiments, copper flux into the perfusate per $g$ of wet gill tissue $\left(\mu \mathrm{mol} \mathrm{g}^{-1}\right)$ was determined cumulatively based on the accumulation of ${ }^{64} \mathrm{Cu}$ radioactivity in the effluent perfusate over the $3 \mathrm{~h}$ of incubation time, the mass of the gill, and the specific activity of the incubation media, and was calculated as:

$\operatorname{Jin}_{\mathrm{P}}=\frac{R_{\mathrm{P}}}{\mathrm{SA} \cdot W_{\mathrm{G}}}$

where $\operatorname{Jin}_{\mathrm{P}}$ is the influx of copper into the perfusate, $R_{\mathrm{P}}$ is the radioactivity $(\mathrm{cpm})$ in the perfusate, $S A$ is the mean specific activity $\left(\mathrm{cpm} \mu \mathrm{M}^{-1}\right)$ of the incubation medium for each flux period and $W_{\mathrm{G}}$ is the wet weight of the gill $(\mathrm{g})$.

Copper uptake into the gill per $g$ of wet gill tissue was calculated by the equation:

$\operatorname{Jin}_{\mathrm{G}}=\frac{R_{\mathrm{G}}}{\mathrm{SA} \cdot W_{\mathrm{G}}}$

where $\operatorname{Jin}_{G}$ is the influx of copper into the gill, $R_{\mathrm{G}}$ is the final radioactivity $(\mathrm{cpm})$ in the gill, SA is the mean specific activity in the incubation media $\left(\mathrm{cpm} \mu \mathrm{M}^{-1}\right)$ between the beginning and the end of the experiment $(3 \mathrm{~h})$, and $W_{\mathrm{G}}$ the wet weight of the gill $(\mathrm{g})$.

Measurements of copper uptake rate from water per $g$ of wet whole crab $\left(\mu \mathrm{mol} \mathrm{g}^{-1} \mathrm{~h}^{-1}\right)$ in the in vivo experiments were calculated based on the formula:

Jin $=\frac{\left(\left[R_{1}\right]-\left[R_{2}\right]\right) \cdot V}{\mathrm{SA} \cdot W_{\mathrm{C}} \cdot T}$

where Jin is copper uptake rate into the crab, $R_{1}$ and $R_{2}$ are the radioactivity values of the ${ }^{64} \mathrm{Cu}$ per $\mathrm{ml}\left(\mathrm{cpm} \mathrm{ml}^{-1}\right)$ in water at the beginning and at the end of the respective 1-h uptake period, $V$ is the water volume of the experimental medium (1000 ml), SA is the mean specific activity $\left(\mathrm{cpm} \mu \mathrm{mol}^{-1}\right)$ of the isotope during the flux period, $W_{\mathrm{c}}$ is the weight of the $\operatorname{crab}(\mathrm{g})$, and $T$ is the time of 1-h flux period.

Copper flux rate into hemolymph per $g$ of wet whole crab $\left(\mu \mathrm{mol} \mathrm{g}{ }^{-1} \mathrm{~h}^{-1}\right.$ ) was calculated based on ${ }^{64} \mathrm{Cu}$ radioactivity measured in hemolymph, on the appropriate specific activity of ${ }^{64} \mathrm{Cu}$ in the water, incubation time, estimated hemolymph volume, and crab body mass as shown by the equation:

$\operatorname{Jin}_{\mathrm{H}}=\frac{\left(\left[R_{\mathrm{i}}\right]-\left[R_{\mathrm{f}}\right]\right) \cdot \mathrm{HV}}{\mathrm{SA} \cdot W_{\mathrm{C}} \cdot T}$

where $\operatorname{Jin}_{\mathrm{H}}$ is the flux rate of copper into hemolymph, $R_{\mathrm{i}}$ and $R_{\mathrm{f}}$ are the radioactivity values of the ${ }^{64} \mathrm{Cu}$ per $\mathrm{ml}\left(\mathrm{cpm} \mathrm{ml}{ }^{-1}\right)$ of hemolymph at the beginning and at the end of the respective uptake interval $(0-1,1-2,2-4,4-6 \mathrm{~h}), \mathrm{HV}$ is total volume of hemolymph in the crab $(\mathrm{ml})$ which was calculated based on data from Wood and Cameron (1985), SA is the mean specific activity (cpm $\mu \mathrm{mol}^{-1}$ $\mathrm{Cu}^{+2}$ ) of the isotope in water during the flux period, $W_{\mathrm{c}}$ is the weight of the crab $(\mathrm{g})$, and $T$ is the time of respective flux period.

Copper uptake into hemolymph ( $\mu \mathrm{mol} \mathrm{g}^{-1}$ wet weight) over the 6 -h period of exposure was calculated based on the on ${ }^{64} \mathrm{Cu}$ radioactivity measured in hemolymph at each exposure time (1, $2,4,6 \mathrm{~h}$ ), on the appropriate specific activity of ${ }^{64} \mathrm{Cu}$ in the water at the respective time of exposure, estimated hemolymph volume, and crab body mass. 
Table 1

Physicochemical parameters of the experimental media used in the experiments with the blue crab Callinectes sapidus. Data are expressed as mean \pm SEM. DOC $=$ dissolved organic carbon. $\left({ }^{*}\right)$ Indicates significantly different mean values for each parameter between salinities.

\begin{tabular}{lcc}
\hline Parameter & Salinity 2 ppt & Salinity 30 ppt \\
\hline Temperature $\left({ }^{\circ} \mathrm{C}\right)$ & $20.1 \pm 0.2$ & $20.3 \pm 0.3$ \\
$\mathrm{pH}$ & $7.12 \pm 0.11$ & $7.28 \pm 0.12$ \\
Dissolved oxygen $\left(\mathrm{mg} \mathrm{L}^{-1}\right)$ & $8.0 \pm 0.4$ & $6.5 \pm 0.2^{*}$ \\
$\mathrm{Na}^{+}\left(\mathrm{mg} \mathrm{L}^{-1}\right)$ & $559.9 \pm 75.2$ & $10626.0 \pm 879.0^{*}$ \\
$\mathrm{Cl}^{-}\left(\mathrm{mg} \mathrm{L}^{-1}\right)$ & $1971.0 \pm 106.7$ & $18185.0 \pm 1737.1^{*}$ \\
$\mathrm{~K}^{+}\left(\mathrm{mg} \mathrm{L}^{-1}\right)$ & $18.8 \pm 1.7$ & $295.2 \pm 34.0^{*}$ \\
$\mathrm{Ca}^{2+}\left(\mathrm{mg} \mathrm{L}^{-1}\right)$ & $20.7 \pm 0.4$ & $340.7 \pm 9.3^{*}$ \\
$\mathrm{Mg}^{2+}\left(\mathrm{mg} \mathrm{L}^{-1}\right)$ & $116.2 \pm 5.4$ & $870.3 \pm 128.8^{*}$ \\
$\mathrm{SO}_{4}{ }^{2-}\left(\mathrm{mg} \mathrm{L}^{-1}\right)$ & $56.2 \pm 2.3$ & $737.5 \pm 21.9^{*}$ \\
$\mathrm{Alkalinity}\left(\mathrm{mg} \mathrm{CaCO}_{3} \mathrm{~L}^{-1}\right)$ & $14.2 \pm 1.7$ & $241.0 \pm 13.8^{*}$ \\
$\mathrm{DOC}\left(\mathrm{mg} \mathrm{L}^{-1}\right)$ & $0.41 \pm 0.10$ & $5.20 \pm 0.77^{*}$ \\
\hline
\end{tabular}

Organ-specific ${ }^{64} \mathrm{Cu}$ distribution ( $\mu \mathrm{mol} \mathrm{g}^{-1}$ wet weight) was calculated based on the amount of ${ }^{64} \mathrm{Cu}$ in each tissue analyzed divided by specific activity of water and crab mass at the end of the 6-h exposure.

\subsection{Statistical analyses}

The trimmed Spearman-Karber method was used to calculate copper concentrations causing mortality of $50 \%$ of the individuals tested (96-h $\mathrm{LC}_{50}$ ) and their corresponding 95\% confidence intervals. Free cupric ion $\left(\mathrm{Cu}^{2+}\right)$ concentration and activity were estimated at 2 and 30 ppt using the Visual MINTEQ software. These estimations were based on the measured dissolved copper concentrations and the water chemistry at the corresponding salinity. Regarding DOC, speciation was performed using the Nica-Donnan model. Therefore, copper speciation analysis was performed as previously described (Pinho and Bianchini, 2010).

In general, data from both in vivo and in vitro experiments have been expressed as mean \pm standard error of mean. Mean values comparisons were performed using one-way analysis of variance (ANOVA) followed by the Tukey's test. Differences between mean values of copper flux to the gills and to the perfusate were evaluated using the two-tailed Student's t-test. Differences between rates of copper uptake into the tissues analyzed (anterior gills, posterior gills, hepatopancreas, gonads, hemolymph) and rest of the body in the in vivo tests were evaluated by ANOVA followed by the Tukey's test.

Relationships between free cupric ion concentration or free cupric ion activity in the experimental media or gill (anterior and posterior) copper burden and \% mortality, at salinity 2 and $3 \mathrm{ppt}$, were evaluated by linear regression analysis.

In all cases, the significance level adopted was 95\% $(\alpha=0.05)$.

\section{Results}

The physicochemical parameters of the experimental media employed in the experiments with the blue crab $C$. sapidus are shown in Table 1 . As expected a higher dissolved oxygen concentration was observed in saltwater at salinity $2 \mathrm{ppt}$, while higher alkalinity and concentration of ions and dissolved organic carbon were observed in saltwater at salinity $30 \mathrm{ppt}$. Regarding $\mathrm{pH}$, no significant difference was observed between salinities.

Acute toxicity values at salinities of 2 and 30 ppt are compared in Table 2. Based on nominal, total, and dissolved copper concentrations, the $96-\mathrm{h} \mathrm{LC} 50$ for copper was 10 -fold lower at 2 ppt than at 30 ppt. However, no significant difference was observed between experimental salinities when the $96-\mathrm{h} \mathrm{LC}_{50}$ for copper were calculated based on free cupric ion concentration or activity (Table 2). It is important to note that survival in control crabs (no copper addi-
Table 2

Acute waterborne copper toxicity in juvenile blue crabs Callinectes sapidus ( $N=7$ per concentration tested) acclimated to saltwater at different salinities. Results are expressed as $96-\mathrm{h} \mathrm{LC}_{50}$ values and their corresponding 95\% confidence intervals in $\mu \mathrm{M}$. Toxicity values were calculated based on nominal, total, dissolved, and free cupric ion concentrations, as well as free cupric ion activity. $\left({ }^{*}\right)$ Indicates significant difference $(p<0.05)$ between water salinities for each copper fraction.

\begin{tabular}{llc}
\hline Copper fraction & Salinity $2 \mathrm{ppt}$ & Salinity $30 \mathrm{ppt}$ \\
\hline Nominal & $8.00(5.58-11.46)$ & $112.25(54.63-230.63)^{*}$ \\
Total & $6.39(4.20-9.70)$ & $63.23(34.02-117.51)^{*}$ \\
Dissolved & $5.31(3.50-8.05)$ & $52.99(27.39-102.52)^{*}$ \\
Free ion & $3.09(1.93-4.95)$ & $5.58(2.33-13.37)$ \\
Activity & $1.41(0.88-2.26)$ & $1.70(0.71-4.07)$ \\
\hline
\end{tabular}

tion into the water) was $100 \%$ in both 2 and 30 ppt, confirming the euryhalinity of juvenile $C$. sapidus.

The percentage of total copper that was dissolved in the water $24 \mathrm{~h}$ after metal addition into the experimental media, as well as mortality observed after $96 \mathrm{~h}$ of experiment for each concentration tested at 2 and 30 ppt are shown in Fig. $1 \mathrm{~A}$ and B, respectively. At $2 \mathrm{ppt}$, no copper precipitation was visually observed over the whole range of concentrations tested. On the other hand, at $30 \mathrm{ppt}$, visible copper precipitation increased as a function of metal concentration at exposures higher than $10 \mu \mathrm{M}$ (nominal copper
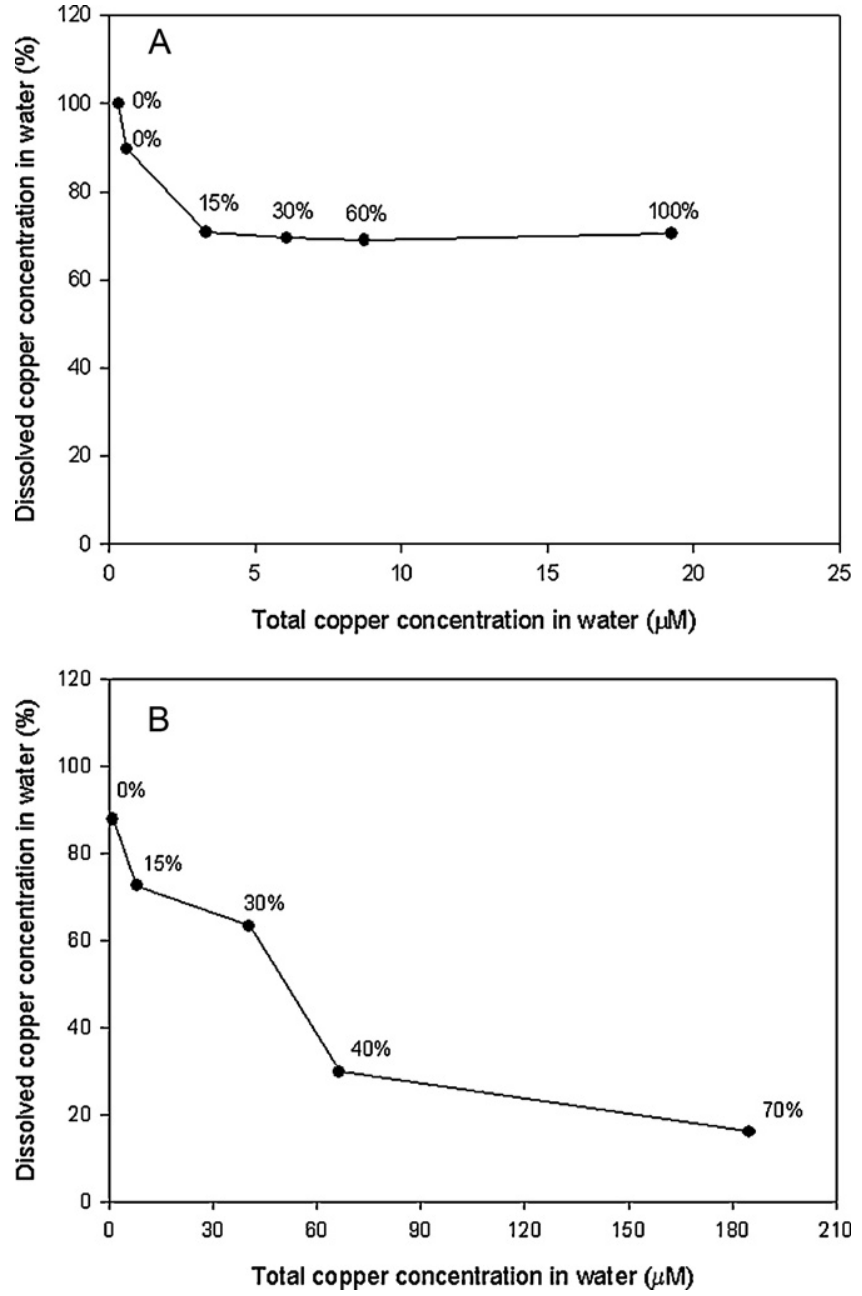

Fig. 1. Percentage of total copper that was measured as dissolved copper after $24 \mathrm{~h}$ after copper addition to the experimental medium. Percentage values above bars represent the corresponding mortality of juvenile blue crabs Callinectes sapidus at each copper concentration tested in saltwater of (A) salinity 2 ppt and (B) salinity $30 \mathrm{ppt}$. 

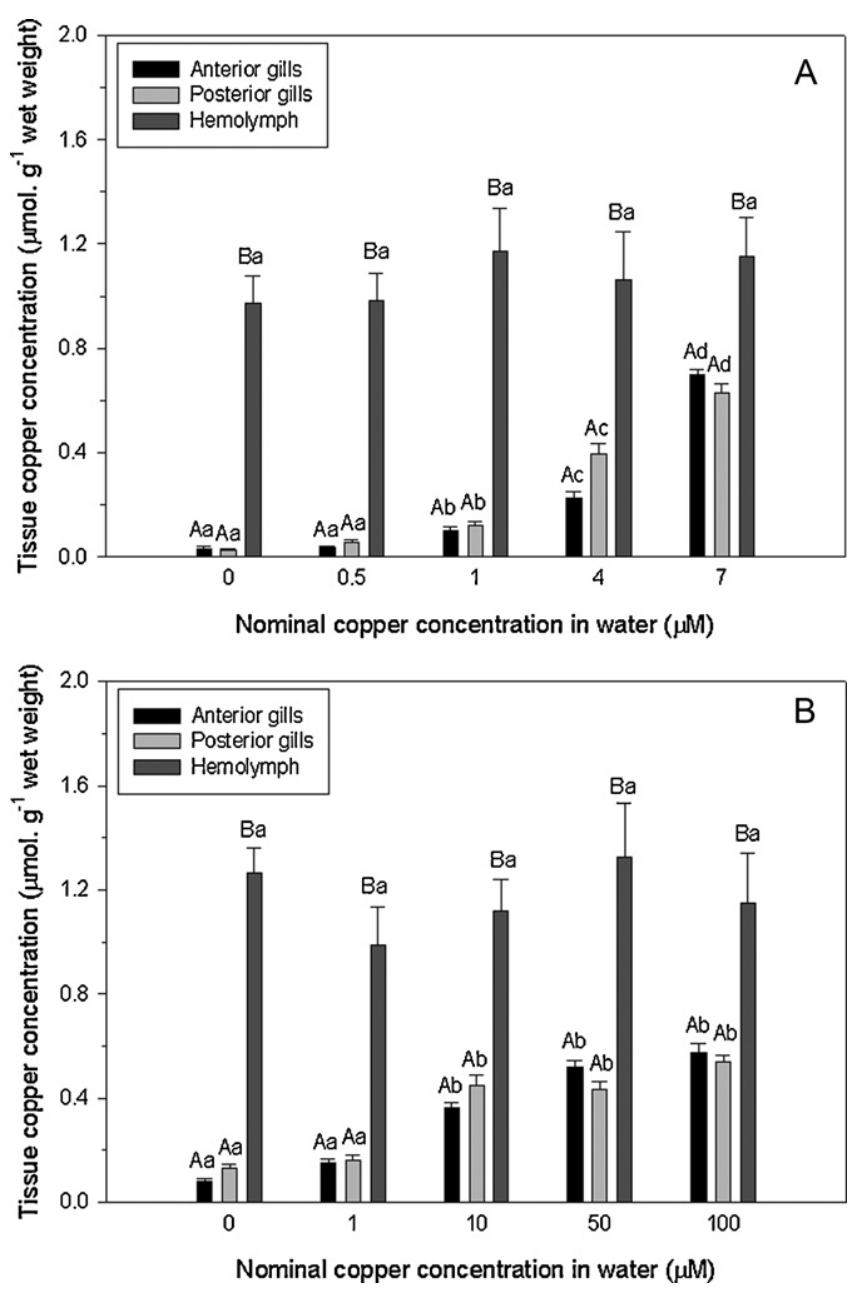

Fig. 2. Gill and hemolymph copper accumulation in juvenile blue crabs Callinectes sapidus kept under control condition (no copper addition into the water) or acutely exposed $(96 \mathrm{~h})$ to waterborne copper in water of $(\mathrm{A})$ salinity $2 \mathrm{ppt}(0.5,1,4$ and $7 \mu \mathrm{M}$ nominal copper) and (B) salinity $30 \mathrm{ppt}(1,10,50$ and $100 \mu \mathrm{M}$ nominal copper). Data are expressed as mean \pm SEM. Different capital letters indicate significant difference $(p<0.05)$ within tissues at the same copper concentration. Different lowercase letters indicate significant difference $(p<0.05)$ within copper concentrations for the same tissue.

concentration), probably as $\mathrm{CuCl}_{2}$. Direct measurement by $0.45 \mu \mathrm{m}$ filtration proved more sensitive than the eye but confirmed the general observation; percentage loss by precipitation never exceeded $25 \%$ at 2 ppt (Fig. 1A), but at 30 ppt, increased progressively with concentration, such that only $20 \%$ of copper remained dissolved at the highest tested concentration (Fig. 1B). As shown in Fig. 1B there was very high copper precipitation at $30 \mathrm{ppt}$ at concentrations lower than those inducing $50 \%$ crab mortality. In preliminary trials at copper concentrations lower than $10 \mu \mathrm{M}$ at $30 \mathrm{ppt}$, crab mortality was consistently below $15 \%$.

Fig. 2 shows the copper content in gills (anterior and posterior) and hemolymph of surviving blue crabs exposed to copper for $96 \mathrm{~h}$ at 2 (Fig. 2A) and $30 \mathrm{ppt}$ (Fig. 2B). At $2 \mathrm{ppt}$, a significant copper accumulation was observed in both anterior and posterior gills of crabs exposed to $1 \mu \mathrm{M}$ nominal copper. Gill copper accumulation was dependent on metal concentration in the experimental media. However, levels of copper in the hemolymph, which were much higher than in the gill, did not significantly change across the different copper concentrations tested (Fig. 2A).

Copper concentrations in tissues of control crabs and those exposed to $1,10,50$, and $100 \mu \mathrm{M}$ nominal copper at $30 \mathrm{ppt}$ are shown in Fig. 2B. A significant copper accumulation was observed
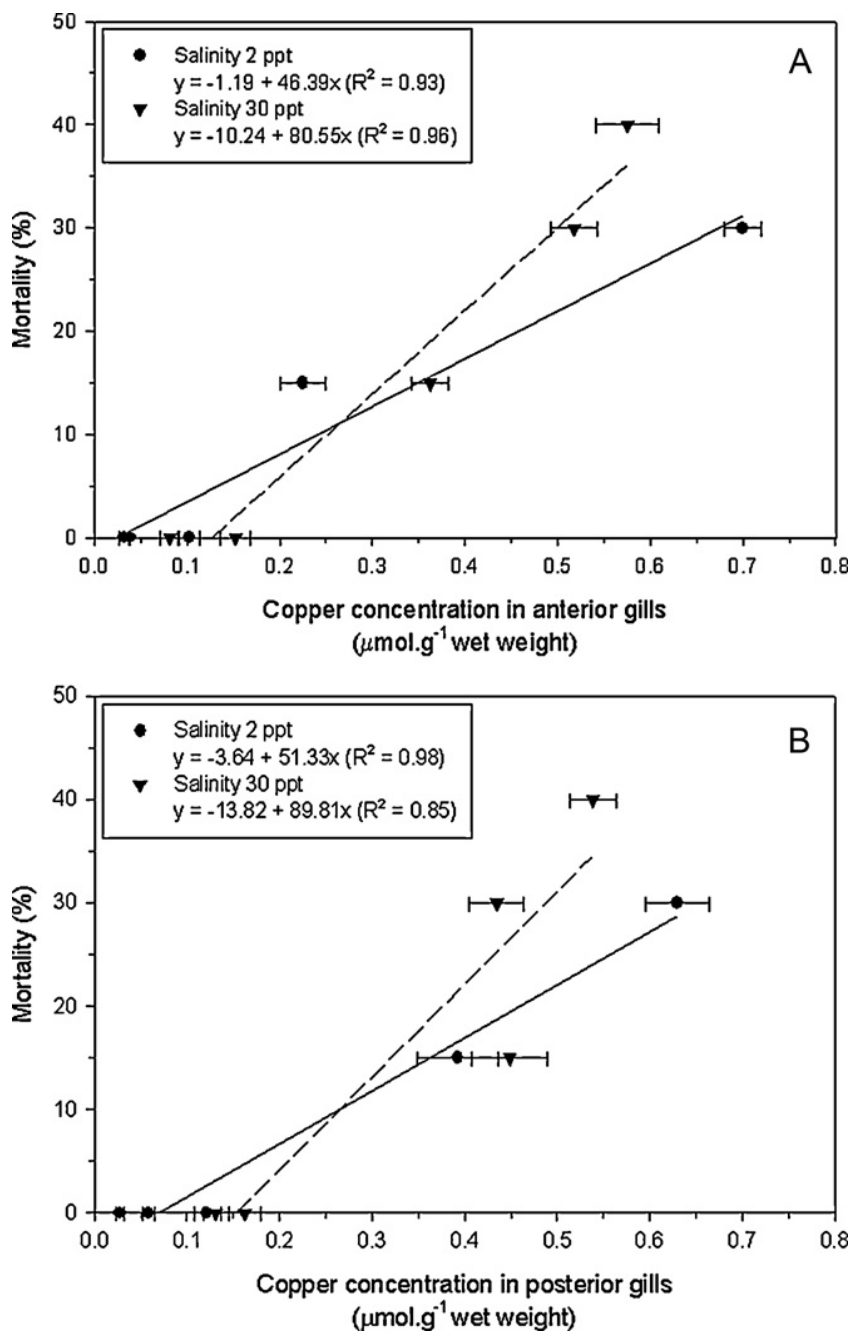

Fig. 3. Relationships between gill copper accumulation and \% mortality in (A) anterior and (B) posterior gills of juvenile blue crabs Callinectes sapidus exposed to copper (96h) at salinity $2 \mathrm{ppt}(0,0.5,1,4$ and $7 \mu \mathrm{M}$ nominal copper $)$ and $30 \mathrm{ppt}(0,1,10,50$ and $100 \mu \mathrm{M}$ nominal copper). Data are expressed as mean \pm SEM.

in both anterior and posterior gills of crabs exposed to concentrations higher than $10 \mu \mathrm{M}$ nominal copper. Gill copper accumulation was similar at 10, 50 and $100 \mu \mathrm{M}$ nominal copper. As observed at $2 \mathrm{ppt}$, copper concentration in the hemolymph was higher than in the gills, and did not change significantly as a function of metal concentration in the experimental medium.

At both 2 and $30 \mathrm{ppt}$, no significant differences in copper concentration were observed between anterior and posterior gills. Furthermore, the relationships between copper concentration in the gills (anterior and posterior) and \% mortality were similar at 2 and $30 \mathrm{ppt}$ (Fig. 3). Also, significant relationships between free cupric ion concentration [( salinity 2 ppt: $y=-0.87+13.11 x$; $R^{2}=0.98$ ) (salinity $30 \mathrm{ppt}: y=1.57+20.16 x ; R^{2}=0.84$ )] or free cupric ion activity $\left[y=-0.87+28.70 x ; R^{2}=0.98\right.$ ) (salinity 30 ppt: $\left.\left.y=3.88+62.61 x ; R^{2}=0.80\right)\right]$ and \% mortality were observed at the two salinities tested.

In vitro copper accumulation was investigated using a gill perfusion technique. Concentrations of copper added to the media ( 1 and $10 \mu \mathrm{M}$ nominal copper) were selected based on data from the in vivo experiments described above. The highest concentration tested $(10 \mu \mathrm{M} \mathrm{Cu})$ was around the nominal copper 96-h $\mathrm{LC}_{50}$ at $2 \mathrm{ppt}$ (Table 2). Measured dissolved copper concentrations at 0 (control), 1 , and $10 \mu \mathrm{M}$ nominal copper treatments were $0.28 \pm 0.03,0.79 \pm 0.08$, and $7.31 \pm 0.25 \mu \mathrm{M}$ in the incubation media 


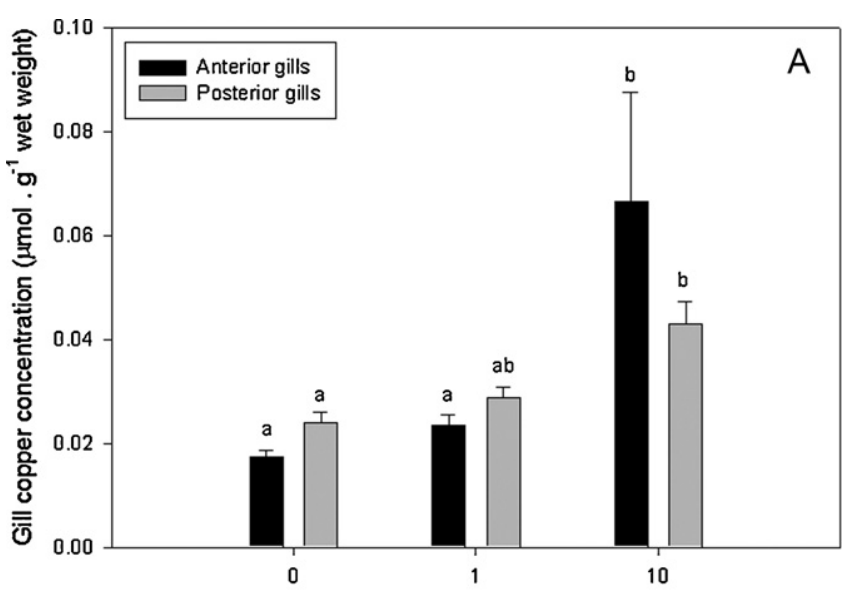

Nominal copper concentration in the incubation medium $(\mu \mathrm{M})$

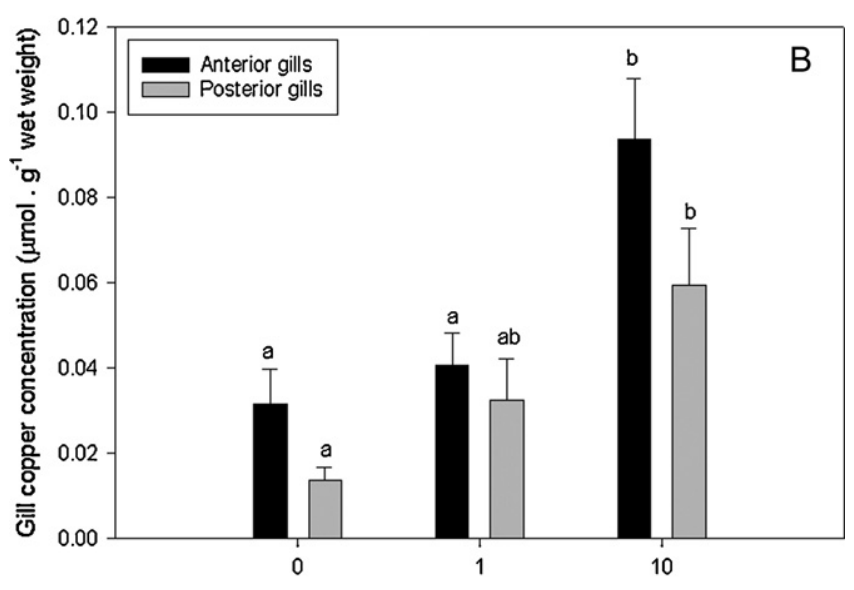

Nominal copper concentration in the incubation medium $(\mu \mathrm{M})$

Fig. 4. Copper accumulation in perfused gills $(N=6)$ (anterior and posterior) isolated from juvenile blue crabs Callinectes sapidus. Gills were (A) perfused with S2 saline solution and incubated with W2 solution or (B) perfused with S30 saline solution and incubated with W30 solution for $4 \mathrm{~h}$. See text for solution compositions. Experiments were performed without (control) or with copper ( 1 and $10 \mu \mathrm{M}$ nominal copper) addition into the incubation media. Data are expressed as mean \pm SEM. Different letters indicate significant difference $(p<0.05)$ within copper concentrations for each type of gill (anterior and posterior). For each copper concentration tested, no significant difference $(p>0.05)$ was observed between anterior and posterior gills.

(W2 solution), and $0.12 \pm 0.03,0.94 \pm 0.06$, and $8.74 \pm 0.39 \mu \mathrm{M}$ in the incubation media (W30 solution), respectively.

At the highest copper concentration tested (10 $\mathrm{MM}$ nominal copper), a significant copper accumulation was observed after $4 \mathrm{~h}$ in both anterior and posterior gills perfused with S2 saline solution and incubated in W2 solution (Fig. 4A) or perfused with S30 saline solution and incubated in W30 solution (Fig. 4B). No significant difference in copper accumulation was observed between anterior and posterior gills in all treatments (Fig. 4). Although copper concentration measured in water from the in vivo and in vitro experiments were quite similar, copper accumulation was much higher in gills of crabs exposed in vivo to copper (Fig. 2) than in those exposed in vitro to copper (Fig. 4). The difference likely reflects the different exposure times $-4 \mathrm{~h}$ in vitro versus $96 \mathrm{~h}$ in vivo.

The time-dependency of copper accumulation in vitro was investigated only in posterior gills (Fig. 5). When gill copper accumulation was analyzed at 1,2 , and $4 \mathrm{~h}$ of perfusion, gills incubated in W2 solution showed a significant copper accumulation only after $4 \mathrm{~h}$ of incubation with $10 \mu \mathrm{M}$ nominal copper. For gills incubated in W30 solution, a significant accumulation of copper was observed after 1 and $4 \mathrm{~h}$ of incubation with $10 \mu \mathrm{M}$ nominal copper.
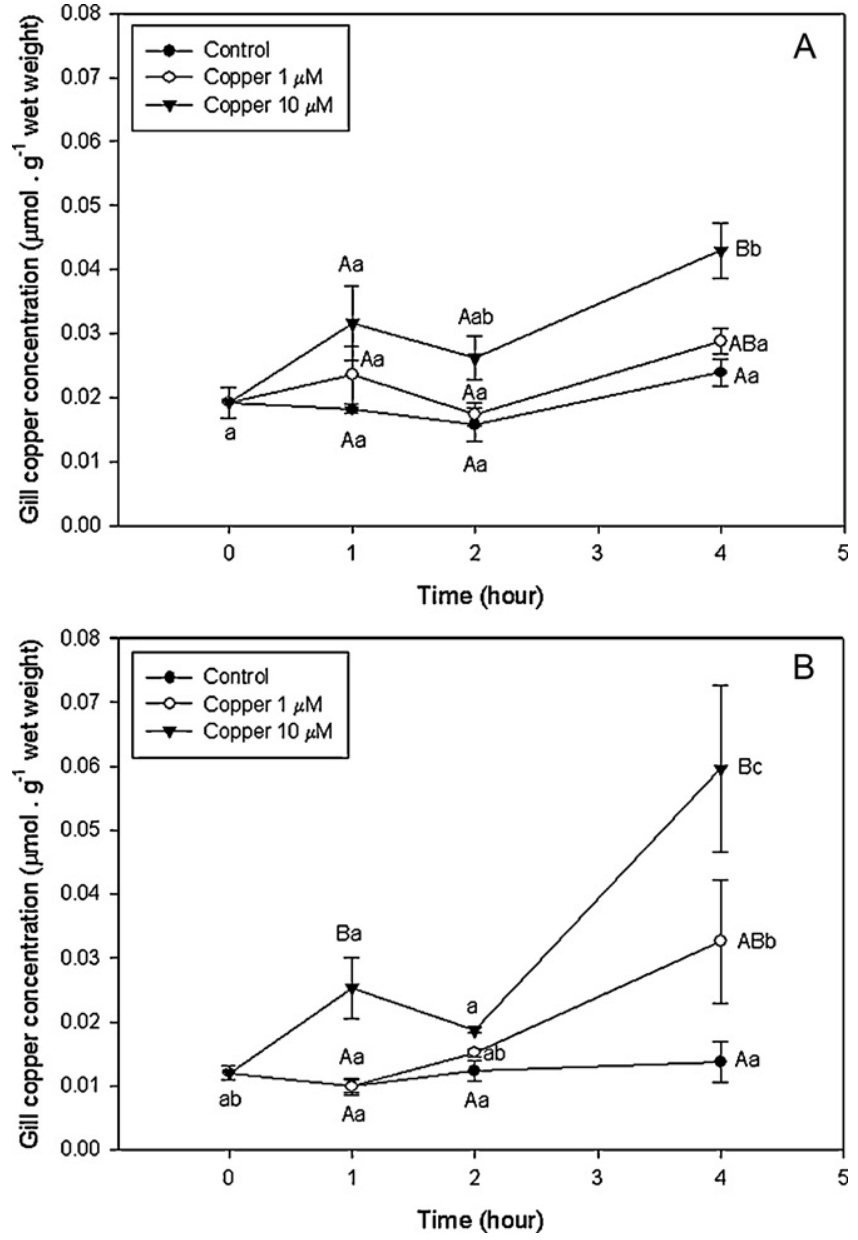

Fig. 5. Time dependent kinetics of copper accumulation in posterior gills $(N=6)$ of juvenile blue crabs Callinectes sapidus (A) perfused with S2 saline solution and incubated with W2 solution or (B) perfused with S30 saline solution and incubated with W30 solution for 1, 2, and $4 \mathrm{~h}$. See text for solution compositions. Experiments were performed without (control) or with copper (1 and $10 \mu \mathrm{M}$ nominal copper) addition into the incubation media. Data are expressed as mean \pm SEM. Different capital letters indicate significant difference $(p<0.05)$ within copper concentrations for the same time of exposure. Different small letters indicate significant difference $(p<0.05)$ within times of exposure for the same copper concentration.

A more sensitive methodology using ${ }^{64} \mathrm{Cu}$ was tested which allowed measurement of copper uptake into both gill tissue and perfusate. Experiments were performed only with posterior gills from crabs acclimated to 2 ppt and perfused with S2 saline solution and incubated in W2 solution. Posterior gills were incubated for $3 \mathrm{~h}$ in $1 \mu \mathrm{M}^{64} \mathrm{Cu}$. Copper flux into the perfusate stayed at a more or less constant level until $130 \mathrm{~min}$, increasing significantly after this period of incubation (Fig. 6). Cumulative copper uptake into the perfusate over the $3 \mathrm{~h}$ perfusion period $\left(39 \pm 8 \times 10^{-6} \mu \mathrm{mol} \mathrm{g}^{-1}\right.$ gill wet weight) was markedly lower than that into the gill tissue by the end of $3 \mathrm{~h}\left(0.008 \pm 0.002 \mu \mathrm{mol} \mathrm{g}^{-1}\right.$ gill wet weight). In fact, copper entering the gills appeared to be well handled in this tissue over the $3 \mathrm{~h}$ of experiment, with only very small amount of this metal flowing into the perfusate. It is important to note that the ${ }^{64} \mathrm{Cu}$ disappearance from the incubation saline solution over $3 \mathrm{~h}\left(0.106 \pm 0.033 \mu \mathrm{mol} \mathrm{g}^{-1}\right.$ gill wet weight $)$ does not match with the sum of the ${ }^{64} \mathrm{Cu}$ going into the gill and into the perfusate. Such difference could be explained considering that a large amount of ${ }^{64} \mathrm{Cu}$ could have been adsorbed onto the walls of the incubation vessel, as well as onto the gill surface. The latter would have been displaced by the "cold displacement" procedure used at the end of the experiment (see Section 2). Notably, copper uptakes into 


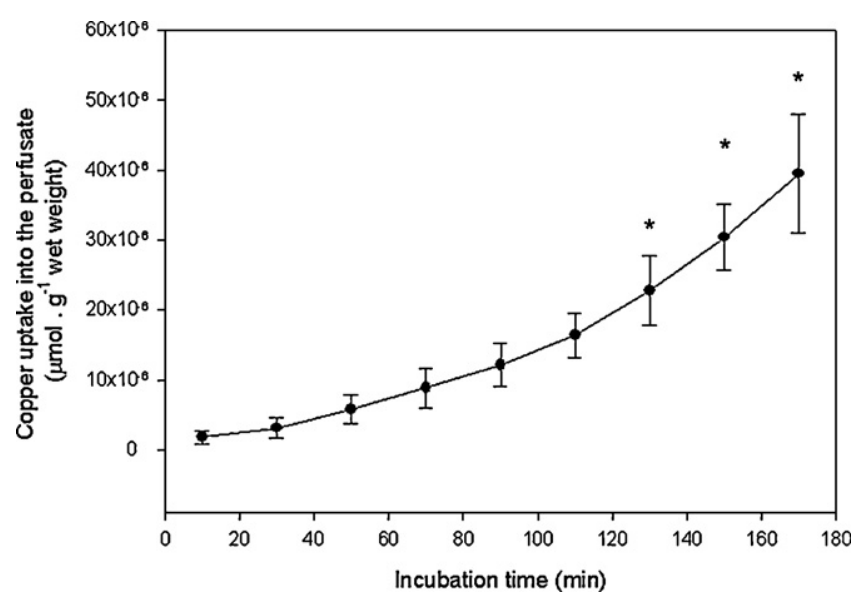

Fig. 6. Cumulative copper $\left({ }^{64} \mathrm{Cu}\right)$ uptake into the gill perfusate over the experimental period. Isolated posterior gills $(N=6)$ of juvenile blue crabs Callinectes sapidus were perfused with S2 saline solution and incubated with W2 solution containing $1 \mu \mathrm{M} \mathrm{Cu}$. See text for solution compositions. Values are expressed as means \pm SEM. $\left.{ }^{*}\right)$ Indicates significantly different $(p<0.05)$ copper uptake rate from that at the beginning of gill perfusion (initial value).

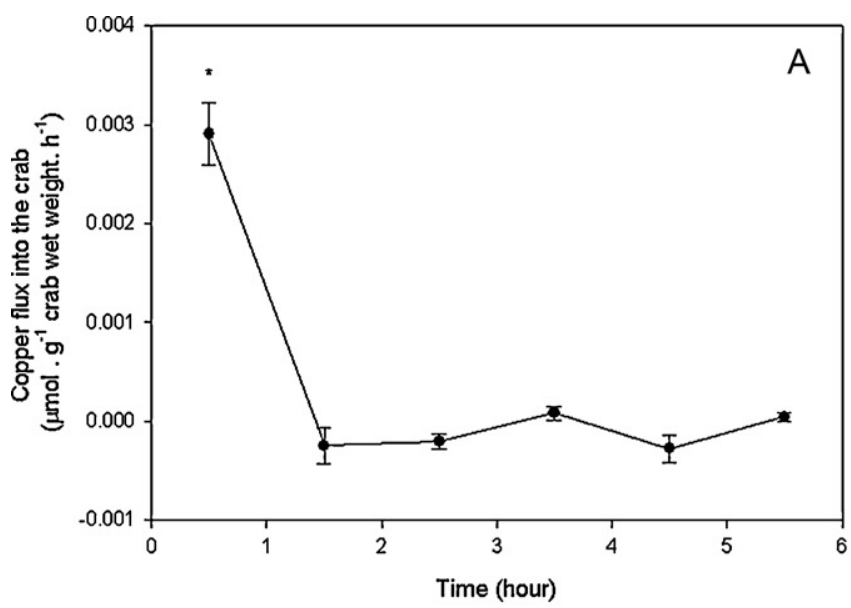

the gills measured using either "cold" $\left(0.005 \pm 0.002 \mu \mathrm{mol} \mathrm{g}^{-1}\right.$ gill wet weight) or radioactive techniques $\left(0.008 \pm 0.002 \mu \mathrm{mol} \mathrm{g}^{-1}\right.$ gill wet weight) were similar over the $3-4 \mathrm{~h}$ of incubation when gills were exposed to $1 \mu \mathrm{M}$ copper. "Cold" copper accumulation was measured by subtracting the control values from those of $1 \mu \mathrm{M}$ exposure over $4 \mathrm{~h}$ (Fig. 5A).

Fig. 7 illustrates the results of the in vivo ${ }^{64} \mathrm{Cu}$ uptake experiment, performed at a nominal concentration of $1 \mu \mathrm{M}^{64} \mathrm{Cu}$ in the incubation medium at $2 \mathrm{ppt}$. Based on the disappearance of ${ }^{64} \mathrm{Cu}$ $\mathrm{cpm}$ from the external water, copper flux into the crab occurred only over the first hour of the incubation; following this period ${ }^{64} \mathrm{Cu}$ did not change significantly in the external media (Fig. 7A). Similar to the disappearance of ${ }^{64} \mathrm{Cu}$ from the medium, ${ }^{64} \mathrm{Cu}$ flux into hemolymph was only observed in the first hour, although this is not significant (Fig. 7B). Furthermore, ${ }^{64} \mathrm{Cu}$ concentration in the hemolymph did not change significantly over time (Fig. 7C). As shown in section 2.6 copper uptake into hemolymph was calculated based on radioactivity of ${ }^{64} \mathrm{Cu}$ in total mass of crab hemolymph, specific activity of water, and crab body mass ( $\mathrm{g}$ ). For copper flux calculations, time of exposure (h) was also considered. These findings could suggest again that copper uptake occurred only over the first hour of exposure, but note that the calculated rate of ${ }^{64} \mathrm{Cu}$ appearance in the haemolymph was only about $2.5 \%$ of the rate of ${ }^{64} \mathrm{Cu}$ disappearance from the external water. This suggests that
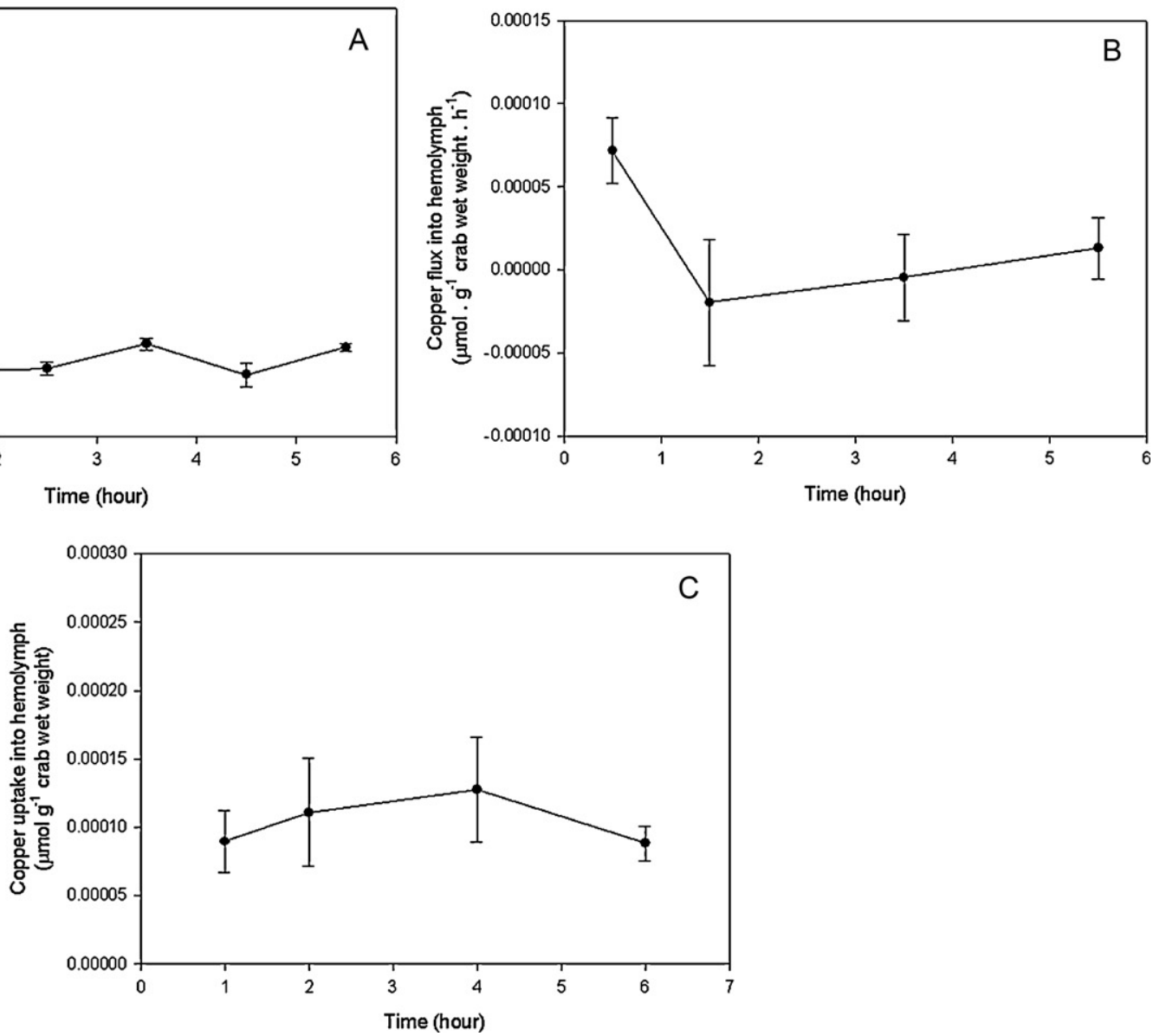

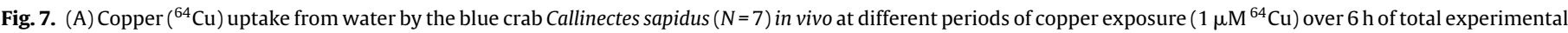

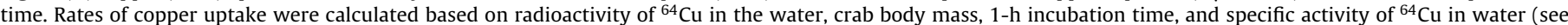

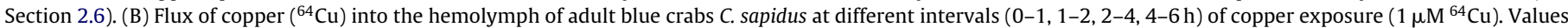

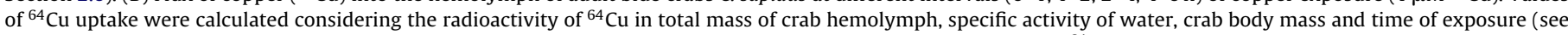

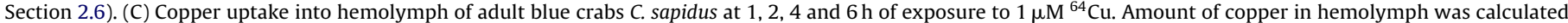

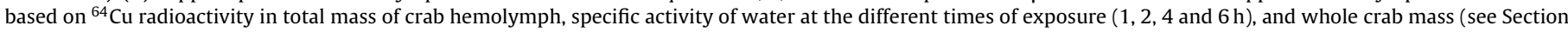

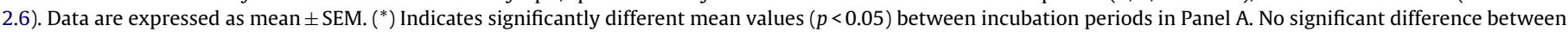
mean values $(p>0.05)$ was observed in Panels B and C. 


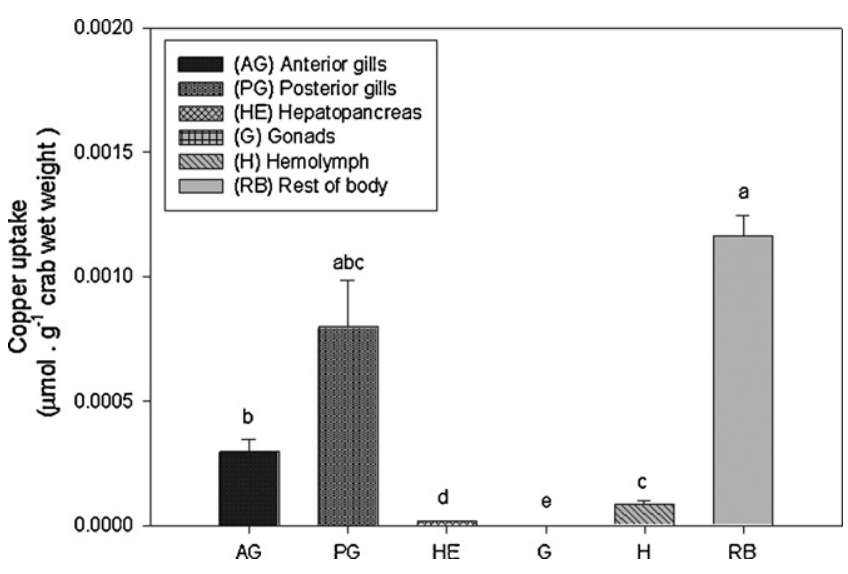

Fig. 8. Copper $\left({ }^{64} \mathrm{Cu}\right)$ distribution in different tissues (hemolymph, anterior and posterior gills, hepatopancreas, gonads, and rest of the body) of adult blue crabs $C$. sapidus $(N=7)$ exposed to $1 \mu \mathrm{M}$ radiolabelled $\mathrm{Cu}$ for $6 \mathrm{~h}$. The amount of copper in each tissue was calculated based on ${ }^{64} \mathrm{Cu}$ radioactivity, specific activity of water at the end of exposure period ( $6 \mathrm{~h}$ ), and whole crab mass. "Rest of the body" represents mainly the exoskeleton and muscle. Data are expressed as mean \pm SEM. Different letters indicate significantly different mean values $(p<0.05)$ among tissues.

most of the ${ }^{64} \mathrm{Cu}$ disappearing from the external water was being redistributed to other sites in the crab.

Terminal sampling occurred after $6 \mathrm{~h}$ of exposure. The organspecific copper distribution was calculated as the amount of ${ }^{64} \mathrm{Cu}$ that appeared in each tissue in relation to the total ${ }^{64} \mathrm{Cu}$ incorporated by crab over $6 \mathrm{~h}$ of experiment (Fig. 8). The largest percentage (52\%) of ${ }^{64} \mathrm{Cu}$ taken up by the adult blue crabs in vivo was found in the "rest of the body". However, the gills (43\%) also seem to have an important role in copper accumulation. Note that there was only $4 \%$ in the haemolymph at this time, in agreement with the flux calculation, and the percentage in the hepatopancreas $(0.8 \%)$ was also very low. Overall, there was good agreement between the amounts of ${ }^{64} \mathrm{Cu}$ removed from water in the first hour of exposure period to that appearing in the whole crab at $6 \mathrm{~h}(0.0029 \pm 0.003$ and $0.0024 \pm 0.0002 \mu \mathrm{M}$ copper per $\mathrm{g}$ of whole wet crab mass, respectively).

\section{Discussion}

Acute waterborne copper toxicity data obtained in the present study for the blue crab, Callinectes sapidus, show that $96-\mathrm{h} \mathrm{LC}_{50}$ values based on nominal, total and dissolved copper concentrations calculated for salinity 2 ppt were $\sim 10$-fold lower than that for salinity $30 \mathrm{ppt}$. However, 96-h $\mathrm{LC}_{50}$ values calculated based on free copper concentration and activity were not significantly differently between 2 and $30 \mathrm{ppt}$ (Table 2). Furthermore, copper burden in the gills (anterior and posterior) seems to be the main factor controlling copper toxicity in the blue crabs (Fig. 3).

According to the Biotic Ligand Model (BLM), acute dissolved copper toxicity occurs when metal binds to active sites in the biotic ligand (i.e gills of fish and crustaceans). However, copper speciation, bioavailability, and its subsequent toxicity to aquatic organisms are highly dependent on the water physicochemical parameters (e.g., $\mathrm{pH}$, alkalinity, hardness, ions and dissolved organic matter concentrations, among others) (Paquin et al., 2000; Santore et al., 2001). Water chemistry parameters widely vary between salinities tested in present study ( 2 and $30 \mathrm{ppt}$ ). For example, $\mathrm{Na}^{+}, \mathrm{Mg}^{2+}$ and $\mathrm{Ca}^{2+}$ concentrations at salinity $30 \mathrm{ppt}$ are $\sim 20$-fold higher than at $2 \mathrm{ppt}$, whereas $\mathrm{Cl}^{-}$concentration increases $\sim 10$-fold (Table 1). Cations present in seawater, such as $\mathrm{Na}^{+}, \mathrm{Mg}^{2+}$, and $\mathrm{Ca}^{2+}$ may compete with copper for the active binding sites in the biotic ligand (gills of fish and crustaceans) (Lauren and McDonald, 1986; Grosell and Wood, 2002) while anions, mainly $\mathrm{Cl}^{-}$, complex with copper, reducing its bioavailability (Bianchini et al., 2004). Therefore, with increasing salinity, an increased tolerance for copper would be expected. In fact, several authors have shown a decrease in copper toxicity in fish and crustaceans with an increase in water salinity (Bambang et al., 1995; Chen and Lin, 2001; Grosell et al., 2007).

Salinity affects not only the physical chemistry of the water, but also the physiology of the animal. The blue crab hyperosmoregulates at 2 ppt and osmoconforms at 30 ppt (Leffler, 1975). Active transbranchial $\mathrm{NaCl}$ absorption and water excretion via the antennal gland constitute the major elements of the hyperosmoregulatory processes in order to compensate the passive $\mathrm{NaCl}$ loss and water entry to the dilute external medium. On the other hand, the osmotic stress is low in water at high salinities, with internal osmotic concentrations close to that of the surrounding medium (Henry and Cameron, 1982; Pequeux, 1995; Freire et al., 2008). Considering that copper generally targets ion transport mechanisms (Grosell and Wood, 2002; Grosell et al., 2002, 2007), it seems reasonable to suggest that variations in copper sensitivity at low and high salinities would be associated with the different osmoregulatory strategies adopted by $C$. sapidus under these experimental conditions ( 2 and $30 \mathrm{ppt}$ ). Grosell et al. (2007) demonstrated that the highest tolerance of the euryhaline fish Fundulus heteroclitus to copper occurs close to the isosmotic point of this species, when the osmotic stress is least, suggesting that copper tolerance is more associated with physiological aspects of the organism than with the metal bioavailability in the media. However, it is important to point out that these authors did not vary the free copper concentration very widely ( $<4$-fold) in comparison to the variation in salinity ( $>10$-fold). Therefore, the water chemistry effect would be relatively limited while the physiological effects associated with the variation in salinity would be somewhat accentuated.

In turn, results reported here for the euryhaline blue crab $C$. sapidus are not in agreement with this idea. Despite the fact that the isosmotic point for blue crabs corresponds to a water salinity of $\sim 30 \mathrm{ppt}$, where the crab sensitivity to total copper was much lower, the 96-h $\mathrm{LC}_{50}$ values calculated based on free copper concentration and activity were not significantly different from the values at $2 \mathrm{ppt}$. This finding clearly indicates that acute waterborne copper toxicity observed in the blue crab $C$. sapidus are not associated with the physiological aspects, but are solely explained by changes in water chemistry at the two different experimental salinities. It also suggests that the free cupric ion would be responsible for the acute toxicity observed at the different salinities tested. In fact, a significant positive relationship between mortality and free cupric ion concentration or activity was observed. Thus, the copper precipitation at $30 \mathrm{ppt}$ (Fig. 1B), the differences in organism physiology between 2 and $30 \mathrm{ppt}$, and the additional cations present at the higher salinity do not appear to influence copper toxicity in C. sapidus. At this point, one could consider the possibility that the mechanism of acute copper toxicity at high salinities would not be associated with an ionic imbalance, as observed in freshwater animals. This could explain why the additional cations present in saltwater at salinity $30 \mathrm{ppt}$ would not be influencing the acute copper toxicity in the blue crab. In fact, it has been suggested that copper can also cause mortality through respiratory disruption (Grosell et al., 2002).

As far as we know, this work is the first to report copper acute toxicity in juvenile $C$. sapidus. However, data of copper toxicity $(96 \mathrm{~h})$ tests are also available for juveniles of other marine and estuarine decapods (Bambang et al., 1995; Chen and Lin, 2001; Valdovinos and Zuniga, 2002; Ferrer et al., 2006). Acute copper toxicity is similar in both the juveniles euryhaline crabs Neohelice granulata and $C$. sapidus in very dilute seawater $(\sim 2 \mathrm{ppt}$ ) (Bianchini et al., 2003). However, at high salinity the blue crab is more sensitive to copper than N. granulata (Lopez Greco et al., 2001; Ferrer et al., 2006). Also, the shrimp Penaeus mondon is more tolerant to cop- 
per than blue crab (Chen and Lin, 2001) at high salinity while the shrimp Penaeus japonicas is less sensitive (Bambang et al., 1995). The variation in sensitivity among species could be due to differences in size and also to differences in physiology (Grosell et al., 2007).

The relationships between copper burden in the gills and mortality were very similar at 2 and $30 \mathrm{ppt}$ (Fig. 3). This suggests that copper concentration in gills is the key factor controlling copper toxicity in blue crabs, in accord with the BLM framework. Indeed, many previous studies have been shown the gills are the site of acute dissolved copper toxicity in aquatic organisms (Lauren and McDonald, 1985; Taylor and Anstiss, 1999; Vitale et al., 1999; Wood, 2001; Grosell and Wood, 2002; Grosell et al., 2007). At 2 ppt, gill accumulation of copper showed a positive relationship between exposure concentrations and metal burden in gills (Fig. 2A). In contrast, significant copper accumulation in gills of crabs acclimated to $30 \mathrm{ppt}$ was observed only after exposure to $10 \mu \mathrm{M}$ or higher nominal copper concentrations (Fig. 2B). Increased copper concentrations following metal exposure were also found in gills of the crabs Carcinus maenas (Weeks et al., 1993) and Pachygrapsus marmoratus (Legras et al., 2000). Generally, crustaceans take up copper in proportion to dissolved copper in the media (Rainbow, 1995).

In the blue crab, anterior gills are considered as mainly respiratory and posterior gills are the major sites for ion transport (Piller et al., 1995; Towle and Weihrauch, 2001). Therefore, high copper concentrations in the gills can cause osmoregulatory disturbances and/or respiratory disruption (Grosell et al., 2002). In freshwater animals, physiological studies have demonstrated that copper inhibits sodium uptake by the gills through competition with sodium uptake pathways and also inhibits the activity of the $\mathrm{Na}^{+} / \mathrm{K}^{+}$-ATPase, a basolateral enzyme responsible for sodium transport uptake (Lauren and McDonald, 1985, 1986; Grosell et al., 2002). On the other hand, disturbances in acid-base balance presumably caused by restriction of gas exchange capacity have been reported for the shore crab C. maenas after acute exposure to copper (Boitel and Truchot, 1988, 1990). Also, an inhibition of the activity of the carbonic anhydrase was observed in the estuarine crab N. granulata following copper exposure (Vitale et al., 1999). Since carbonic anhydrase is involved in osmoregulation as well as in gas exchange, an inhibition of its activity can cause both osmoregulatory and respiratory disorders. Despite the different roles of anterior and posterior gills, no significant difference in copper accumulation was detected between these two types in either in vivo or in vitro experiments with "cold" Cu.

In contrast to the results observed for gills, copper concentrations in the hemolymph, which were much higher than in gill tissue, did not change as a function of copper concentration in the experimental media (Fig. 2). Since copper is a functional part of the crustacean respiratory protein hemocyanin (Engel and Brouwer, 1987; Rainer and Brouwer, 1993), high concentrations of the metal in the hemolymph are expected. Previous studies have shown that copper taken up from the ambient water and reaching the hemolymph is removed to other organs to be detoxified or excreted, maintaining copper level in the hemolymph relatively constant (Rtal and Truchot, 1996; Rainbow, 2002; Rainbow, 2007). This would explain the unchanged levels of copper in the hemolymph of blue crabs $C$. sapidus exposed to different copper concentrations. Due to the affinity of metals, including copper, for protein-SH and -NH groups, the extra copper incorporated by the crab could bind to the non-active sites in the hemocyanin and be transported through the body until reaching the detoxifying organs such as the hepatopancreas.

Copper concentration increased in isolated-perfused gills (anterior and posterior) after $4 \mathrm{~h}$ of incubation in W2 or W30 solutions containing $10 \mu \mathrm{M}$ copper (Figs. 4 and 5). Furthermore, the amount of copper accumulated in vitro was similar in gills incubated in W2 and W30 solutions. This similarity in copper accumulation was also observed in gills of crabs exposed in vivo to comparable concentrations of copper in media at 2 and 30 ppt (Fig. 2). The higher levels of copper found in gills from the in vivo experiments (Fig. 2) when compared to those from the in vitro tests (Fig. 4) are likely due to the different times of exposure, i.e., $96 \mathrm{~h}$ for the in vivo and only $4 \mathrm{~h}$ for the in vitro assays. Indeed, if we multiply the accumulation over $4 \mathrm{~h}$ in vitro by $96 / 4=24$, the product is similar or slightly greater than the levels measured in vivo at $96 \mathrm{~h}$. Therefore, the in vitro gill perfusion model seems to be a suitable model to study mechanisms of copper uptake and toxicity in decapods.

Using a more sensitive methodology, i.e. a radiotracer technique based on ${ }^{64} \mathrm{Cu}$, we measured for the first time the in vitro and in vivo influx of copper in a crustacean species. In these experiments, isolated posterior gills or whole crabs were exposed to $1 \mu \mathrm{M}{ }^{64} \mathrm{Cu}$ at a salinity of $2 \mathrm{ppt}$. It should be remembered that $C$. sapidus hyperosmoregulates by active ion pumping at 2 ppt (Henry and Cameron, 1982; Towle and Weihrauch, 2001; Bianchini et al., 2008; Freire et al., 2008).

Measurements of copper influx show that most of the ${ }^{64} \mathrm{Cu}$ taken up by isolated gills accumulates in this tissue and only a small amount of copper moves through to the perfusate (Fig. 6). The amount accumulated in the gill tissue agreed well between radioactive and "cold" methodology. However, as mentioned above, the ${ }^{64} \mathrm{Cu}$ technique revealed that copper influx to the perfusate (hemolymph) significantly increased after $2 \mathrm{~h}$ of incubation and kept increasing through to $3 \mathrm{~h}$ of experiment (Fig. 6). A possible interpretation for these finding is that the mechanisms of transport at the basolateral gill membrane are limiting the copper flux from the gill to the hemolymph, leading to a build-up of concentration of copper inside the gill ion-transporting cells. Once the internal binding sites are saturated, the increased level of copper accumulated inside the gill cells may induce a stimulation of the cellular mechanisms involved in copper extrusion. In this context, Grosell and Wood (2002) have suggested that in rainbow trout copper passes from the gill cells to the blood via copper-specific P-type ATPases. In fact, an involvement of the basolateral $\mathrm{Na}^{+} / \mathrm{K}^{+}$-ATPase in copper transport has been demonstrated in isolated gills of the blue crab C. sapidus acclimated to seawater at salinity $30 \mathrm{ppt}$ (Paganini et al., 2008). Regardless of its details, the mechanism of copper extrusion appears to serve as a protective response against the excessive accumulation of copper in the gill tissue.

Regarding in vivo copper flux, over the first hour of whole crab incubation with ${ }^{64} \mathrm{Cu}$, the amount of ${ }^{64} \mathrm{Cu}$ significantly decreased in the media (Fig. 7A) and increased in hemolymph (Fig. 7B), but not inducing significant changes in hemolymph ${ }^{64} \mathrm{Cu}$ concentration over the 6-h exposure period (Fig. 7C). These results show that a fraction of copper taken up by the crabs, probably throughout the gills, enters the hemolymph, but this is only a very small percentage $(2.5 \%)$ of the total. Most must have been redistributed to other tissues, because by $6 \mathrm{~h}$, the amount measured in the whole crab agreed well with the amount that disappeared from the external medium $(0.0024 \pm 0.0002$ and $0.0029 \pm 0.003 \mu \mathrm{M}$ copper per $\mathrm{g}$ of whole wet crab mass, respectively). Notably, following $1 \mathrm{~h}$ of incubation, ${ }^{64} \mathrm{Cu}$ concentration did not change in the media or in the haemolymph. This may suggest that crabs activated mechanisms to regulate down-regulate copper uptake. One possibility that was not investigated in the present study is that the crabs reduced or stopped their ventilation of the external media in the face of a noxious stimulus. Crabs are capable of long ventilatory pauses (McDonald et al., 1977).

Although not significant, ${ }^{64} \mathrm{Cu}$ appeared to decrease in hemolymph following the first hour of the experiment (Fig. 7B), suggesting that ${ }^{64} \mathrm{Cu}$ absorbed by the crabs is being regulated internally by an intrinsic mechanism. Since hemolymph is a transit compartment for copper, exogenous copper accumulation in this 
tissue is not expected. Also, ${ }^{64} \mathrm{Cu}$ did not appear to exchange with the large amount of non-radioactive copper ( cold $\mathrm{Cu}^{+2}$ ) present in the hemolymph. Perhaps exogenous copper transits in the hemolymph in a different pool from that of "cold copper" which is probably associated with the hemocyanin.

Measurements of organ-specific ${ }^{64} \mathrm{Cu}$ distribution demonstrated that the gills are important sites of copper accumulation in the blue crab (Fig. 8). This would be expected since metal uptake in gill-breathing animals generally takes place at the gills. The high rates of copper uptake observed in gills of $C$. sapidus reinforce the idea that this is a target organ for copper accumulation and toxicity. Notably, ${ }^{64} \mathrm{Cu}$ accumulation was greater in posterior gills, which are considered to be the major sites for ion transport (Piller et al., 1995; Towle and Weihrauch, 2001); this was not detected with the less sensitive cold techniques.

The gill epithelium may not be the sole target for the toxic action of copper. The hepatopancreas has also been described as an important organ of metal storage and detoxification in crustaceans (Legras et al., 2000; Rainbow, 2007). However, ${ }^{64} \mathrm{Cu}$ burden in this tissue was low (0.8\%) when compared to posterior gills $(30.7 \%)$ and "rest of the body" (52\%). Perhaps, the shorter period of exposure and lower copper concentration used for $C$. sapidus in the present study did not allow copper $\left({ }^{64} \mathrm{Cu}\right)$ to accumulate to high levels in the crab hepatopancreas.

As observed for gills, a large amount of ${ }^{64} \mathrm{Cu}$ was also found in the "rest of the body", which is essentially composed of muscles and exoskeleton. In fact, exoskeleton can adsorb much of the dissolved labeled copper. This metal can be desorbed again at lower dissolved exposures. However, it is never taken up into the body and consequently cannot exert toxic effects. However, it must be stressed that the adsorbed copper onto the exoskeleton was displaced and washed out after rinsing the blue crabs in a concentrated $(200 \mu \mathrm{M})$ cold-copper solution. Therefore, copper measured in the blue crab exoskeleton can be considered as effectively accumulated in the tissue. Part of the copper taken up by gills or the gut may be transported into the exoskeleton via the hypodermal lining of the cuticle. In this case, it can even be resorbed again before molting, being physiologically available for a certain time. This copper might or might not exert toxic effects. On the other hand, copper storage in the exoskeleton can be a strategy for metal elimination, because crustaceans replace the old carapace containing excessive amounts of metal by a new and "clean" one during the molting process (Steenkamp et al., 1994; Pourang et al., 2004). In this case, copper accumulated in exoskeleton would not be available for binding to sensitive sites, where the metal can exert toxic effects.

Clearly, as in fish (Grosell et al., 1997; Grosell and Wood, 2002) the ${ }^{64} \mathrm{Cu}$ technique is a powerful one, revealing information in $C$. sapidus that would be difficult to gather from "cold" experiments. In future investigations, it will be profitable to sacrifice crabs at various times, so as to track changes in uptake and internal distribution after various durations of exposure, as well as to measure changes in ventilation (McDonald et al., 1977) during the exposure.

Finally, different approaches employed in the present study (in vitro and in vivo techniques both with and without ${ }^{64} \mathrm{Cu}$ ) to measure gill copper uptake and accumulation are in agreement and all of them point to the gills as the main target for acute dissolved copper toxicity in C. sapidus.

\section{Conclusions}

Differences in acute waterborne copper toxicity observed between experimental salinities ( 2 and $30 \mathrm{ppt}$ ) appear to be completely explained by changes in water chemistry, and apparently were not dependent on the different physiological aspects of blue crabs at different water salinities. This finding is in agreement with the similar pattern of tissue metal accumulation observed in the juvenile blue crab $C$. sapidus at the different experimental salinities, especially in the gills (anterior and posterior), and in the similar relationships between gill copper burden and mortality at the two salinities. Also, measurements of copper influx reinforce the role of gills in copper uptake, accumulation, and toxicity. Further investigations are necessary to identify the pathways involved in copper uptake by gills of the blue crab C. sapidus, as well as to better understand the mechanisms of acute waterborne copper toxicity over a wider range of water salinities.

\section{Acknowledgements}

We wish to thank Mariana Machado Lauer (Universidade Federal do Rio Grande, Rio Grande, RS, Brazil) for helpful communications and Sunita Nadella (McMaster University, Hamilton, ON, Canada) for laboratory assistance. This study was financially supported by the Conselho Nacional de Desenvolvimento Científico e Tecnológico (CNPq) from Brazil in the scope of the Instituto Nacional de Ciência e Tecnologia de Toxicologia Aquática (INCT-TA) and the International Development Research Centre (IDRC) from Canada. Work in Canada was supported by a grant from the International Copper Association. C.M.G. Martins is a graduate fellow from the Brazilian CAPES. C.M. Wood is supported by the Canada Research Chair Program. A. Bianchini is a research fellow from the Brazilian CNPq (Proc. 304430/2009-9) and is supported by the International Canada Research Chair Program from IDRC.

\section{References}

Arnold, W.R., Santore, R.C., Cotsifas, J.S., 2005. Predicting copper toxicity in estuarine and marine waters using the biotic ligand model. Mar. Pollut. Bull. 50, 1634-1640.

Bambang, Y., Charmantier, G., Thuet, P., Trilles, J.P., 1995. Effect of cadmium on survival and osmoregulation of various developmental stages of the shrimp Penaeus japonicus (Crustacea: Decapoda). Mar. Biol. 123, 443-450.

Baumgarten, M.G.Z., Niencheski, L.F., 1998. Avaliação da qualidade hidroquímica da área portuária da cidade de Rio Grande - RS. Documentos Técnicos 09, FURC Editora, Rio Grande.

Bianchini A., Martins, S.E., Pedroso, M.S., Said, J.S., Spengler, A., 2003. Biotic ligand model in fresh and sea water in Brazil. In: Lagos, G.E., Warner, A.E.M., Sánchez, M. (Eds.), Health, environment and sustainable development, vol. II. Proceedings of the Copper 2003. The 5th International Conference, Santiago, pp. 543-552.

Bianchini, A., Gilles, R., 2000. Is the digestive tract an important access route for mercury in the Chinese crab Eriocheir sinensis (Crustacea, Decapoda)? Bull. Environ. Contam. Toxicol. 64, 412-417.

Bianchini, A., Grosell, M., Gregory, S.M., Wood, C.M., 2002. Acute silver toxicity in aquatic animals is a function of sodium uptake rate. Environ. Sci. Technol. 36 , 1763-1766.

Bianchini, A., Lauer, M.M., Nery, L.E.M., Colares, E.P., Monserrat, J.M., Santos, E.A. 2008. Biochemical and physiological adaptations in the estuarine crab Neohelice granulata during salinity acclimation. Comp. Biochem. Physiol. A 151, 423-436.

Bianchini, A., Martins, S.E.G., Barcarolli, I.F., 2004. Mechanism of acute copper toxicity in euryhaline crustaceans: implications for the Biotic Ligand Model. Int. Congr. Ser. 1275, 189-194.

Boitel, F., Truchot, J.P., 1988. Acid-base-equilibrium and ion concentrations in the crab Carcinus maenas exposed to sublethal and lethal concentrations of copper ions. Arch. Int. Physiol. Biochim. Biophys. 96, A415-A1415.

Boitel, F., Truchot, J.P., 1990. Comparative study of the effects of copper on hemolymph ion concentrations and acid-base-balance in shore crabs Carcinus maenas acclimated to full-strength or dilute seawater. Comp. Biochem. Physiol C 95, 307-312.

Chen, J.C., Lin, C.H., 2001. Toxicity of copper sulfate for survival, growth, molting and feeding of juveniles of the tiger shrimp, Penaeus monodon. Aquaculture 192, 55-65.

D’Adamo, R., Di Stasio, M., Fabbrocini, A., Petitto, F., Roselli, L., Volpe, M.G., 2008. Migratory crustaceans as biomonitors of metal pollution in their nursery areas. The Lesina lagoon (SE Italy) as a case study. Environ. Monit. Assess. 143, 15-24.

De Schamphelaere, K.A.C., Heijerick, D.G., Janssen, C.R., 2002. Refinement and field validation of a biotic ligand model predicting acute copper toxicity to Daphnia magna. Comp. Biochem. Physiol. C 133, 243-258.

Di Toro, D.M., Allen, H.E., Bergman, H.L., Meyer, J.S., Paquin, P.R., Santore, R.C., 2001 Biotic ligand model of the acute toxicity of metals. 1. Technical basis. Environ. Toxicol. Chem. 20, 2383-2396.

Drach, P., Tchernigovtzeff, C., 1967. Sur la méthode de détermination des stades d'intermue et son application générale aux crustacés. Vie Milieu 18, 597-607. 
Engel, D.W., Brouwer, M., 1987. Metal regulation and molting in the blue crab, Callinectes sapidus: metallothionein function in metal metabolism. Biol. Bull. 173, 239-251.

Ferrer, L., Andrade, S., Asteasuain, R., Marcovecchio, J., 2006. Acute toxicities of four metals on the early life stages of the crab Chasmagnathus granulata from Bahía Blanca estuary, Argentina. Ecotoxicol. Environ. Saf. 65, 209-217.

Flegal, A.R., Sanudo-Wilhelmy, S.A., 1993. Comparable levels of trace metal contamination in two semi-enclosed embayments: San Diego Bay and south San Francisco Bay. Environ. Sci. Technol. 27, 1934-1936.

Freire, C.A., Onken, H., McNamara, J.C., 2008. A structure-function analysis of ion transport in crustacean gills and excretory organs. Comp. Biochem. Physiol. A 151, 272-304.

Gensemer, R.W., Naddy, R.B., Stubblefield, W.A., Hockett, J.R., Santore, R., Paquin, P., 2002. Evaluating the role of ion composition on the toxicity of copper to Ceriodaphnia dubia in very hard waters. Comp. Biochem. Physiol. C 133, 87-97.

Grosell, M., Blanchard, J., Brix, K.V., Gerdes, R., 2007. Physiology is pivotal for interactions between salinity and acute copper toxicity to fish and invertebrates. Aquat. Toxicol. 84, 162-172.

Grosell, M., Nielsen, C., Bianchini, A., 2002. Sodium turnover rate determines sensitivity to acute copper and silver exposure in freshwater animals. Comp. Biochem. Physiol. C 133, 287-303.

Grosell, M., Wood, C.M., 2002. Copper uptake across rainbow trout gills: mechanisms of apical entry. J. Exp. Biol. 205, 1179-1188.

Grosell, M.H., Hogstrand, C., Wood, C.M., 1997. Copper uptake and turnover in both $\mathrm{Cu}$-acclimated and non-acclimated rainbow trout (Oncorhynchus mykiss). Aquat. Toxicol. 38, 257-276.

Henry, R.P., Cameron, J.N., 1982. Acid-base balance in Callinectes sapidus during acclimation from high to low salinity. J. Exp. Biol. 101, 255-264.

Janssen, C.R., Heijerick, D.G., De Schamphelaere, K.A.C., Allen, H.E., 2003. Environmental risk assessment of metals: tools for incorporating bioavailability. Environ. Int. 28, 793-800.

Jones, M.B., 1975. Synergistic effects of salinity, temperature and heavy metals on mortality and osmoregulation in marine and estuarine isopods (Crustacea). Mar. Biol. 30, 13-20.

Lauren, D.J., McDonald, D.G., 1985. Effects of copper on branchial ionoregulation in the rainbow trout, Salmo gairdneri Richardson - modulation by water hardness and pH. J. Comp. Physiol. B 155, 635-644.

Lauren, D.J., McDonald, D.G., 1986. Influence of water hardness, pH, and alkalinity on the mechanisms of copper toxicity in juvenile rainbow trout, Salmo gairdneri. Can. J. Fish. Aquat. Sci. 43, 1488-1496.

Leffler, C.W., 1975. Ionic and osmotic regulation and metabolic response to salinity of juvenile Callinectes sapidus Rathbun. Comp. Biochem. Physiol. 52A, 545549.

Legras, S., Mouneyrac, C., Amiard, J.C., Amiard-Triquet, C., Rainbow, P.S., 2000. Changes in metallothionein concentrations in response to variation in natura factors (salinity, sex, weight) and metal contamination in crabs from a metal-rich estuary. J. Exp. Mar. Biol. Ecol. 246, 259-279.

Lopez Greco, L.S., Sánchez, M.V., Nicoloso, G.L., Medesani, D.A., Rodríguez, E.M., 2001. Toxicity of copper and cadmium on larval and juvenile stages of the estuarine crab Chasmagnathus granulata (Brachyura Grapsidae). Arch. Environ. Contam. Toxicol. 41, 333-338.

MacRae, R.K., Smith, D.E., Swoboda-Colberg, N., Meyer, J.S., Bergman, H.L., 1999 Copper binding affinity of rainbow trout (Oncorhynchus mykiss) and brook trout (Salvelinus fontinalis) gills: implications for assessing bioavailable metal. Environ. Toxicol. Chem. 18, 1180-1189.

Martins, C.M.G., Bianchini, A., 2009. Metallothionein-like proteins in the blue crab Callinectes sapidus: effect of water salinity and ions. Comp. Biochem. Physiol. A 152, 366-371.

McDonald, D.G., McMahon, B.R., Wood, C.M., 1977. Patterns of heart and scaphognathite activity in the crab, Cancer magister. J. Exp. Zool. 202, 33-44.

Morillo, J., Usero, J., Gracia, I., 2005. Biomonitoring of trace metals in a mine-polluted estuarine system (Spain). Chemosphere 58, 1421-1430.

Niencheski, L.F., Baumgarten, M.G.Z., 2000. Distribution of particulate trace metal in the southern part of the Patos Lagoon estuary. Aquat. Ecosyst. Health Manag. 3, 515-520.

Niencheski, L.F.H., Baraj, B., Windom, H. L., França, R.G., 2006. Natural background assessment and its anthropogenic contamination of $\mathrm{Cd}, \mathrm{Pb}, \mathrm{Cu}, \mathrm{Cr}, \mathrm{Zn}, \mathrm{Al}$ and Fe in the sediments of the Southern Area of Patos Lagoon. J. Coast. Res. 39 SI 1040-1043.

Paganini, C.L., Souza, M.M., Bianchini, A., 2008. Gill ion transport and copper accumulation in the blue crab Callinectes sapidus. Comp. Biochem. Physiol. C 148, 461.

Paquin, P.R., Gorsuch, J.W., Apte, S., Batley, G.E., Bowles, K.C., Campbell, P.G.C., Delos C.G., Di Toro, D.M., Dwyer, R.L., Galvez, F., Gensemer, R.W., Goss, G.G., Hogstrand, C., Janssen, C.R., McGeer, J.C., Naddy, R.B., Playle, R.C., Santore, R.C., Schneider,
U., Stubblefield, W.A., Wood, C.M., Wu, K.B., 2002. The Biotic Ligand Model: a historical overview. Comp. Biochem. Physiol. C 133, 3-35.

Paquin, P.R., Santore, R.C., Wu, K.B., Kavvadas, C.D., Di Toro, D.M., 2000. The biotic ligand model: a model of the acute toxicity of metals to aquatic life. Environ. Sci. Pollut. 3, 175-182.

Pequeux, A., 1995. Osmotic regulation in crustaceans. J. Crust. Biol. 15, 1-60.

Pequeux, A., Gilles, R., 1978. Osmoregulation of the eryhaline Chinese crab Eriocheir sinensis. Ionic transport across isolated perfused gills as related to the salinity of environment. In: McLusky, D.S., Berry, A.J. (Eds.), Physiology and Behaviour of Marine Organisms. Pergamon Press, Oxford, pp. 105-111.

Piller, S., Henry, R., Doeller, J., Kraus, D., 1995. A comparison of the gill physiology of two euryhaline crab species, Callinectes sapidus and Callinectes similis: energy production, transport-related enzymes and osmoregulation as a function of acclimation salinity. J. Exp. Biol. 198, 349-358.

Pinho, G.L.L., Bianchini, A., 2010. Acute copper toxicity in the euryhaline copepod Acartia tonsa: implications for the development of an estuarine and marine Biotic Ligand Model. Environ. Toxicol. Chem 29, 1834-1840.

Pinho, G.L.L., Pedroso, M.S., Rodrigues, S.C., Souza, S.S., Bianchini, A., 2007. Physiological effects of copper in the euryhaline copepod Acartia tonsa: waterborne versus waterborne plus dietborne exposure. Aquat. Toxicol. 84, 62-70.

Pourang, N., Dennis, J.H., Ghourchian, H., 2004. Tissue distribution and redistribution of trace metal elements in shrimp species with emphasis on the roles of metallothionein. Ecotoxicology 13, 509-533.

Rainbow, P.S., 1995. Biomonitoring of heavy metal availability in the marine environment. Mar. Pollut. Bull. 31, 183-192.

Rainbow, P.S., 2002. Trace metal concentrations in aquatic invertebrates: why and so what? Environ. Pollut. 120, 497-507.

Rainbow, P.S., 2007. Trace metal bioaccumulation: models, metabolic availability and toxicity. Environ. Int. 33, 576-582.

Rainer, J., Brouwer, M., 1993. Hemocyanin synthesis in the blue crab Callinectes sapidus. Comp. Biochem. Physiol. B 104, 69-73.

Rathbun, M., 1930. The cancroid crabs of America of the families, Euryalidae, Portunidae, Atelecyclidae, Cancridae and Xanthidae. U. S. Natl. Mus. Bull. 152, pp. 609 .

Reardon, I.S., Harrell, R.M., 1990. Acute toxicity of formalin and copper sulfate to striped bass fingerlings held in varying salinities. Aquaculture 87, 255-270.

Rtal, A., Truchot, J.P., 1996. Haemolymph transport and tissue accumulation of exogenous copper in the shore crab, Carcinus maenas. Mar. Pollut. Bull. 32, $802-811$.

Santore, R.C., Di Toro, D.M., Paquin, P.R., Allen, H.E., Meyer, J.S., 2001. Biotic ligand model of the acute toxicity of metals. 2. Application to acute copper toxicity in freshwater fish and Daphnia. Environ. Toxicol. Chem. 20, 2397-2402.

Seeliger, U., Knak, R.B., 1982. Estuarine metal monitoring in southern Brazil. Mar. Pollut. Bull. 13, 253-254

Steenkamp, V.E., du Preez, H.H., Schoonbee, H.J., van Eden, P.H., 1994. Bioaccumulation of manganese in selected tissue of freshwater crab, Potamonautes warreni (Calman), from industrial and mine-polluted freshwater ecosystems. Hydrobiologia 288, 137-150

Taylor, H.H., Anstiss, J.M., 1999. Copper and haemocyanin dynamics in aquatic invertebrates. Mar. Freshw. Res. 50, 907-932.

Towle, D.W., Weihrauch, D., 2001. Osmoregulation by gills of euryhaline crabs: molecular analysis of transporters. Integr. Comp. Biol 41, 770-780.

Valdovinos, C., Zuniga, M., 2002. Copper acute toxicity tests with the sand crab Emerita analoga (Decapoda: Hippidae): a biomonitor of heavy metal pollution in Chilean coastal seawater? Bull. Environ Contam. Toxicol. 69, 393-400.

van Geen, A., Luoma, S.N., 1999. The impact of human activities on sediments of San Francisco Bay, California: an overview. Mar. Chem. 64, 1-6.

Verslycke, T., Vangheluwe, M., Heijerick, D., De Schamphelaere, K., Van Sprang, P., Janssen, C.R., 2003. The toxicity of metal mixtures to the estuarine mysid Neomysis integer (Crustacea: Mysidacea) under changing salinity. Aquat. Toxicol. 64, 307-315.

Vitale, A.M., Monserrat, J.M., Castilho, P., Rodriguez, E.M., 1999. Inhibitory effects of cadmium on carbonic anhydrase activity and ionic regulation of the estuarine crab Chasmagnathus granulata (Decapoda, Grapsidae). Comp. Biochem. Physiol. C 122, 121-129.

Weeks, J.M., Jensen, F.B., Depledge, M.H., 1993. Acid-base status, haemolymph composition and tissue copper accumulation in the shore crab Carcinus maenas exposed to combined copper and salinity stress. Mar. Ecol. Prog. Ser. 97, 91-98.

Wood, C.M., 2001. Toxic responses of the gill. In: Benson, W.H., Schleuh, D.W. (Eds.), Target Organ Toxicity in Marine and Freshwater Teleosts. Taylor \& Francis, Washington, DC, pp. 1-87.

Wood, C.M., Cameron, J.N., 1985. Temperature and the physiology of intracellular and extracellular acid-base regulation in the blue crab Callinectes sapidus. J. Exp. Biol. 114, 151-179. 